Article

\title{
The effect of cAMP and the role of Epac2A during activation, activity, and deactiva- tion of beta cell networks
}

\author{
Maša Skelin Klemen ${ }^{1}$, Jurij Dolenšek ${ }^{2}$, Lidija Križančić Bombek ${ }^{3}$, Viljem Pohorec ${ }^{4}$, Marko Gosak ${ }^{5}$, Marjan Slak \\ Rupnik ${ }^{6}$ and Andraž Stožer ${ }^{7, *}$
}

1 Institute of Physiology, Faculty of Medicine, University of Maribor, Maribor, Slovenia; masa.skelin@um.si

2 Institute of Physiology, Faculty of Medicine, University of Maribor, Maribor, Slovenia and Faculty of Natural sciences and Mathematics, Maribor, Slovenia; jurij.dolensek@um.si

3 Institute of Physiology, Faculty of Medicine, University of Maribor, Maribor, Slovenia; lidija.bombek@um.si

4 Institute of Physiology, Faculty of Medicine, University of Maribor, Maribor, Slovenia; viljem.pohorec@um.si

5 Institute of Physiology, Faculty of Medicine, University of Maribor, Maribor, Slovenia and Faculty of Natural sciences and Mathematics, Maribor, Slovenia; marko.gosak@um.si

6 Center for Physiology and Pharmacology, Medical University of Vienna, Vienna, Austria; marjan.slakrupnik@meduniwien.ac.at

7 Institute of Physiology, Faculty of Medicine, University of Maribor, Maribor, Slovenia; andraz.stozer@um.si

* Correspondence: andraz.stozer@um.si; Tel.:+38622455843

\begin{abstract}
:
Beta cells couple stimulation by glucose with insulin secretion and impairments in this coupling play a central role in diabetes mellitus. To clarify the effect of cAMP and the role of Epac2A in intracellular calcium signals and intercellular coupling, we performed functional multicellular calcium imaging in beta cells in mouse pancreas tissue slices after stimulation with glucose and forskolin in wild-type and Epac2A knock-out mice. Increased cAMP evoked calcium signals in otherwise sub-stimulatory glucose and beta cells from Epac2A knock-out mice displayed a faster activation. During the plateau phase, beta cells from Epac2A knock-out mice displayed a slightly higher active time in response to glucose compared with wild-type littermates, and increased cAMP increased the active time via a large increase in oscillation frequency and small decrease in oscillation duration in both Epac2A knock-out and wild-type mice. Functional network properties during stimulation with glucose did not differ in Epac2A knock-out mice, but the presence of Epac2A was crucial for the protective effect of increased cAMP in preventing a decline in beta cell functional connectivity with time. Finally, increased cAMP prolonged beta cell activity during deactivation in an Epac2A-independent manner.
\end{abstract}

Keywords: pancreas; tissue slices; beta cells; calcium imaging; amplifying pathway; forskolin; Epac2A KO

\section{Introduction}

Insulin serves as an important regulator of nutrient homeostasis and a lack of its effects, either due to beta cell failure or resistance in peripheral tissues, or both, results in diabetes mellitus, which affects more than 463 million people worldwide [1]. $90 \%$ of all diabetes can be attributed to type 2 diabetes mellitus (T2DM), which is characterized by impaired insulin secretion, insulin resistance, and obesity [2]. Numerous drugs are being developed to target different molecular mechanisms of insulin signaling. Sulfonylureas (SUs) target the rudimentary component of the insulin-release mechanism, i.e., the 
ATP-dependent potassium (KATP) channels, responsible for initiation of the triggering pathway of insulin secretion. However, the past few decades have provided knowledge of complementary amplifying pathways that are responsible for fine regulation of insulin secretion, which expands the pool of potential therapeutic targets in T2DM management.

It has been well established that gut hormones, such as the glucagon-like peptide 1 (GLP-1) and the glucose-dependent insulinotropic peptide (GIP), collectively designated as incretins, augment glucose-stimulated insulin secretion (GSIS) by binding to G protein-coupled receptors (GPCR) [3-7]. Activation of their small Gos subunit in turn stimulates adenylyl cyclase (AC) to convert ATP to cAMP, which serves as the second messenger for various intracellular effects [8]. Incretin-induced cAMP elevation potentiates both phases of insulin secretion [9-11] by increasing whole-cell $\mathrm{Ca}^{2+}$ currents through phosphorylation of L-type voltage dependent calcium channels (VDCC) and through $\mathrm{Ca}^{2+}$ mobilization from internal stores [12-16]. This calcium-induced calcium release (CICR) from endoplasmic reticulum (ER) works in concert with cAMP-mediated sensitization of the intracellular $\mathrm{Ca}^{2+}$ release mechanism [15,17-19] and with increased sensitivity of the exocytotic machinery to $\mathrm{Ca}^{2+}[20]$. Due to the stimulatory effects of incretins at various steps in the stimulus-secretion coupling (SSC) cascade, they are excellent candidates for development of T2DM therapies.

Pancreatic beta-cells act as sensors for changes in blood glucose concentration and respond to them with changes in insulin secretion via a process termed stimulus-secretion coupling, by activation of the triggering and amplifying pathway [21,22]. The triggering pathway is initiated by entry of glucose into beta-cells through glucose transporters (GLUT), followed by glucose metabolism and intracellular ATP concentration increase, which results in decreased open probability of the KAтP channels. The subsequent decrease in potassium efflux depolarizes the cell membrane, leading to an increase in permeability of VDCC that enables the influx of $\mathrm{Ca}^{2+}$ ions into the cytoplasm [23]. Being the central intracellular messenger, $\mathrm{Ca}^{2+}$ activates exocytosis of insulin-containing granules [21,24,25].

The triggering pathway is augmented and fine-tuned by amplifying pathways which start with either (i) increased [ $\mathrm{Ca}^{2+}$ ]IC [26], (ii) activation of GPCRs [27], or (iii) with activation of phospholipase C (PLC) [28]. The result of either $\left[\mathrm{Ca}^{2+}\right]_{\mathrm{IC}}$ elevation or GPCR activation is enhanced activity of AC, which increases the concentration of cAMP, an important intracellular secondary messenger. Consequently, cAMP enhances fusion of insulin-containing vesicles with plasma membrane via both a protein kinase $\mathrm{A}$ (PKA)-dependent pathway and activation of the guanine nucleotide exchange protein 2 (Epac2A) [29-31].

PKA-dependent amplification increases insulin release by regulating key components of the SSC cascade, with greater impact on the second phase of insulin secretion compared to the first phase [11]. It has been demonstrated that PKA influences the plasma membrane potential by inhibiting KATP channel activity in an ADP-dependent manner, when glucose levels are high [32], as well as by inhibition of $\mathrm{K}^{+}$currents via voltage dependent KV1.4 channels [33,34]. Further enhancement of $\mathrm{Ca}^{2+}$ signals can be mediated through VDCCs $[13,14,35]$ or $\mathrm{Ca}^{2+}$ mobilization from internal stores $[13,14,16,35]$ or $\mathrm{Ca}^{2+}$ mobilization from internal stores $[15,16]$. It has also been demonstrated that PKA increases the number of insulin-containing granules that are highly sensitive to $\mathrm{Ca}^{2+}[36,37]$, increases the mobility and replenishment of the readily releasable pool (RRP) of insulin-containing granules [29], and increases the overall sensitivity of the secretory machinery to $\left[\mathrm{Ca}^{2+}\right] \mathrm{IC}[20]$.

Along with influences on PKA, cAMP also affects insulin secretion via the cAMP-regulated guanine exchange factor (cAMP-GEF) initially termed Epac2, but subsequently redesignated as Epac2A [31,38-40] which has been implicated in both the first and the second phase of insulin secretion [11,31]. While the Epac1 isoform is ubiquitous, Epac2A is located mainly in the neural, endocrine, and neuroendocrine tissue $[39,41]$, and seemingly predominant in mouse islets [42], as well as in INS-1 cells [43]. The effects 
of Epac2A on insulin secretion are mediated in a myriad of ways. It has been proposed that GLP-1-induced mitochondrial ATP synthesis, which contributes to closure of KATP channels, is at least partially mediated by Epac2A [44]. Furthermore, Epac2A contributes to increased activity of the enzyme glucokinase, increasing the production of substrates for mitochondrial metabolism (Park, 2012). The KATP channels responsible for depolarization of the plasma membrane and subsequent increase in $\left[\mathrm{Ca}^{2+}\right] \mathrm{Ic}$, exhibit increased ATP sensitivity under the influence of Epac2A, facilitating membrane depolarization $[45,46]$. Epac2A influences [ $\left.\mathrm{Ca}^{2+}\right]$ Ic dynamics not only indirectly through the effects on KATP channels but also by RYR-2 sensitization, encouraging $\mathrm{Ca}^{2+}$ release from the endoplasmic reticulum $\mathrm{Ca}^{2+}$ stores upon stimulation with increased $\left[\mathrm{Ca}^{2+}\right] \mathrm{IC}$, a process designated as calcium-induced calcium release CICR $[47,48]$. The facilitation of CICR is most likely mediated via the Rap protein and PLC- $\varepsilon$ [19]. Epac2A may also augment $\mathrm{Ca}^{2+}$ influx by influencing VDCCs via Rim $2 \alpha[49,50]$. Downstream from [ $\left.\mathrm{Ca}^{2+}\right] \mathrm{IC}$, Epac $2 \mathrm{~A}$ increases insulin secretion by increasing the size of the readily releasable pool of granules through Epac2/Rap1 signaling. It also influences docking and priming when complexed with the Rab3-interacting molecule $\operatorname{Rim} 2 \alpha$ [50], and stimulates insulin granule acidification by regulation of $\mathrm{Cl}^{-}$influx, a step important in granule priming [30]. Previous research with Epac2A KO mice has demonstrated a propensity for obesity [51], a diminished first phase of insulin secretion [31], and impaired GSIS, however, this was observed only with diet-induced insulin resistance, not under basal conditions [52].

Besides exhibiting complex and intertwined intracellular signaling pathways, beta cells are intrinsically highly heterogeneous and operate in a multicellular environment. They communicate with each other through different mechanisms, whereby the electrical coupling through gap-junctions is recognized as the main synchronizing agent that facilitates the spreading of depolarization and $\mathrm{Ca}^{2+}$ waves across the islets [53-58]. This enables beta cells to operate in a coordinated manner, which was found essential for the normal control of hormone secretion [21,59-61]. However, due to their multi-faced cell-to-cell variability, the resulting multicellular activity is not completely synchronized and manifests itself in the form of non-stationary waves, guided by the intrinsic islet heterogeneity [62-66]. In recent years, graph-theoretical approaches have been used as powerful methodology to quantify this non-trivial spatio-temporal behavior within the islets [67-69]. By this means, functional connectivity networks are typically constructed based on statistical similarity of $\mathrm{Ca}^{2+}$ traces and previous research has shown that the beta cells form architectures with high communication capacities that are locally segregated into functional subcompartments [70,71]. Moreover, beta cell networks are highly heterogeneous and some very well-connected cells, which were identified as metabolically highly active, are believed to be crucial for routing information between cells [72-74]. However, the role of different signaling pathways in the coordination of the collective cellular rhythms in islets, and particularly the role of cAMP signaling are incompletely understood. Previous studies suggest that intracellular cAMP concentration influences gap-junctional coupling between beta cells [75-79]. Recently, PKA and Epac2A were reported to increase Cx36 gap-junctional coupling by different means $[61,80]$. Noteworthy, data from other tissues also suggests that cAMP serves as a strong modulator of intercellular communication and the effect can be controlled by either arm of the incretin signaling cascade [81-83]. Therefore, it remains of great interest to explore in more detail how neurohormonal amplifying pathways affect multicellular beta cell activity.

In this study, we recorded [ $\left.\mathrm{Ca}^{2+}\right]$ Ic oscillations in a large number of beta cells in acute pancreas tissue slices with single-cell resolution to assess the effect of the cAMP-elevating diterpene forskolin on $\left[\mathrm{Ca}^{2+}\right] \mathrm{IC}$ and determine the contribution of Epac2A in mediating the effects of cAMP on [ $\left.\mathrm{Ca}^{2+}\right]$ Ic. To this end, we performed experiments using forskolin in otherwise sub-stimulatory as well as in stimulatory glucose conditions, in both Epac2A $\mathrm{KO}$ mice and their WT littermates.

\section{Materials and Methods}

2.1. Ethics statement 
The study was conducted as per the protocol approved by the Administration for Food Safety, Veterinary Sector and Plant Protection of the Republic of Slovenia (permit numbers: U3440-1-61/2009/2 and U34401-12/2015/3) and complied with all national and European recommendations relating to care and work with experimental animals to minimize animal discomfort.

\subsection{Tissue slice preparation and dye loading}

Acute pancreas tissue slices were obtained from 12-24 weeks old Epac2A KO mice and their littermates of either sex were kept in individually ventilated cages (Allentown LLC, USA) with a 12:12 hours light: dark schedule, as described previously [54,84]. In brief, mice were sacrificed using high concentration of $\mathrm{CO}_{2}$, and the abdominal cavity was accessed via laparotomy. The pancreas was injected with low-melting point $1.9 \%$ agarose (Lonza, USA) kept at $40^{\circ} \mathrm{C}$ dissolved in extracellular solution (ECS, consisting of (in $\mathrm{mM}$ ) $125 \mathrm{NaCl}, 26 \mathrm{NaHCO}$, 6 glucose, 6 lactic acid, 3 myo-inositol, $2.5 \mathrm{KCl}, 2$ Na-pyruvate, $2 \mathrm{CaCl}$, $1.25 \mathrm{NaH} 2 \mathrm{PO} 4,1 \mathrm{MgCl} 2,0.5$ ascorbic acid) with access through the proximal common bile duct, which was clamped distally at the major duodenal papilla. Following injection, the pancreas was cooled with ice-cold ECS and extracted from the abdominal cavity. A vibratome (VT 1000 S, Leica) was used to create $140 \mu \mathrm{m}$ thick tissue slices, which were collected at RT in HEPES-buffered saline (HBS, consisting of (in $\mathrm{mM}) 150 \mathrm{NaCl}, 10 \mathrm{HEPES}, 6$ glucose, $5 \mathrm{KCl}, 2 \mathrm{CaCl}$, $1 \mathrm{MgCl}$; titrated to $\mathrm{pH}=7.4$ using 1 $\mathrm{M} \mathrm{NaOH})$. The slices were incubated in the dye-loading solution (6 $\mu \mathrm{M}$ Oregon Green 488 BAPTA-1 AM (OGB-1, Invitrogen), 0.03\% Pluronic F-127 (w/v), and 0.12\% dimethylsulphoxide (v/v) dissolved in HBS) for 50 minutes at RT. All chemicals were obtained from Sigma-Aldrich (St. Louis, Missouri, USA) unless otherwise specified.

\subsection{Stimulation protocol and calcium imaging}

Individual tissue slices were exposed to single square pulse-like stimulation per islet in a perifusion system containing carbogenated ECS at $37^{\circ} \mathrm{C}$. Regardless of the number of islets observed on an individual tissue slice, each slice was stimulated with only a single stimulatory protocol. In control experiments, slices were exposed to $12 \mathrm{mM}$ glucose only for 25 minutes, followed by incubation in a solution with substimulatory $6 \mathrm{mM}$ glucose concentration until apparent cessation of activity. In experiments using forskolin slices were exposed to $6 \mathrm{mM}$ or $12 \mathrm{mM}$ glucose for 5 and $15 \mathrm{~min}$, respectively, followed by the addition of $10 \mu \mathrm{M}$ forskolin for $10 \mathrm{~min}$ and the subsequent substimulatory $6 \mathrm{mM}$ glucose concentration again until the deactivation of cells. Calcium imaging was performed on a Leica TCS SP5 DMI6000 CS inverted confocal system (20X HC PL APO water/oil immersion objective, NA 0.7) and a Leica TCS SP5 AOBS Tandem II upright confocal system (20x HCX APO L water immersion objective, NA 1.0). Acquisition frequency was set to $1-2 \mathrm{~Hz}$ at $512 \times 512$ pixels. For a more precise quantification of [ $\mathrm{Ca}^{2+}$ ]IC oscillations, a resolution of $10 \mathrm{~Hz}$ at $256 \times 256$ pixels was maintained throughout the whole stimulation protocol. The laser power was adapted to avoid photobleaching and prolong the maximum time of recording, while maintaining a satisfactory signal strength. Cells were imaged at the approximate depth of $15 \mu \mathrm{m}$ or more to avoid recording from cells at the potentially damaged cut surface. The optical section thickness was kept at about $4 \mu \mathrm{m}$ to assure recordings from a single cell only. OGB-1 was excited by an argon $488 \mathrm{~nm}$ laser line and emitted fluorescence was detected by Leica HyD hybrid detector in the range of 500-700 nm (all from Leica Microsystems, Germany), as described previously [54,57,85].

\subsection{Processing of Ca2+ Signals and Beta Cell Functional Network Analysis}

Individual ROIs were selected manually with respect to cell morphology using a high-resolution image, maximal projection, or frame average. Time series were exported using custom-made software (ImageFiltering, copyright Denis Špelič). Custom-made Matlab and Phyton scripts were used for subsequent off-line analysis. Fluorescence signals were expressed as $\mathrm{F} / \mathrm{F}_{0}$, the ratio of the fluorescence signal $(\mathrm{F})$ at a certain time point of the experiment relative to the initial fluorescence $\left(\mathrm{F}_{0}\right)$. A combination of exponential 
and linear fit was applied to correct the time series data for photobleaching. Time series with distorted signals and those with evident non-beta cell-like features were removed from further analysis. Beginnings of $\left[\mathrm{Ca}^{2+}\right]_{\mathrm{IC}}$ increases and decreases after exposure to high and low glucose were used to manually select activation and deactivation times, respectively.

A zero-lag digital filter was used on $\mathrm{Ca}^{2+}$ traces to extract the classical signaling parameters in the phase of sustained activity, with the purpose of removing noise and possible low frequency baseline variations. This was followed by a process of binarization so that the values from the onset to the end of individual oscillations were 1 , and values between the oscillations were 0 . Binarized time series data was then used for characterization of the oscillatory activity in the following parameters: (i) the average frequency, (ii) the average duration of oscillations, and (iii) the relative active times (AT) of individual cells. The variability of the activation delays was measured by calculating delays relative to the first responding cells in an islet (any-cell-first-responder delays) or to account for the inter-islet differences, dividing the data with the respective islet median delay (relative any-cell-first-responder delays).

To assess the collective beta cell activity in each islet, we generated functional connectivity networks. By this means, nodes represent individual beta cells, and their locations correspond to physical positions of cells in tissue slices. Connections between node pairs were created based on the temporal similarity of the measured $\mathrm{Ca}^{2+}$ dynamics, as evaluated through the calculation of the correlation coefficient [71]. We have used variable thresholds to extract the connectivity matrix, so that the average node degree in each islet, i.e., the average number of connections per cell $\langle k\rangle$, in the first part in the sustained activity phase (12 mM glucose only) was $\langle k>=8$ and the same connectivity threshold was then used in the second part in the phase of sustained activity (either $12 \mathrm{mM}$ glucose or $12 \mathrm{mM}$ glucose $+10 \mu \mathrm{M}$ forskolin) in the same islet. In this way a comparison between different islets was facilitated as well as a direct evaluation of the changes between both intervals. The extracted functional networks were analyzed with common network metrics. Specifically, the average correlation coefficient along with the average node degree were used to evaluate the average level of beta cell synchronicity in the given islet. Modularity was used to characterize the level of functional segregation, i.e., the extent of partitioning into smaller subpopulations, whereas the largest component was used to determine the degree of the network's functional integration. For details, see [71].

\section{Results}

A typical beta cell response to glucose stimulation features three subsequent phases of $\left[\mathrm{Ca}^{2+}\right.$ Ic activity, i.e., the activation, the plateau, and the deactivation phase (Figure 1, $[54,85])$. Below, we present the results according to this order of the three response phases. 

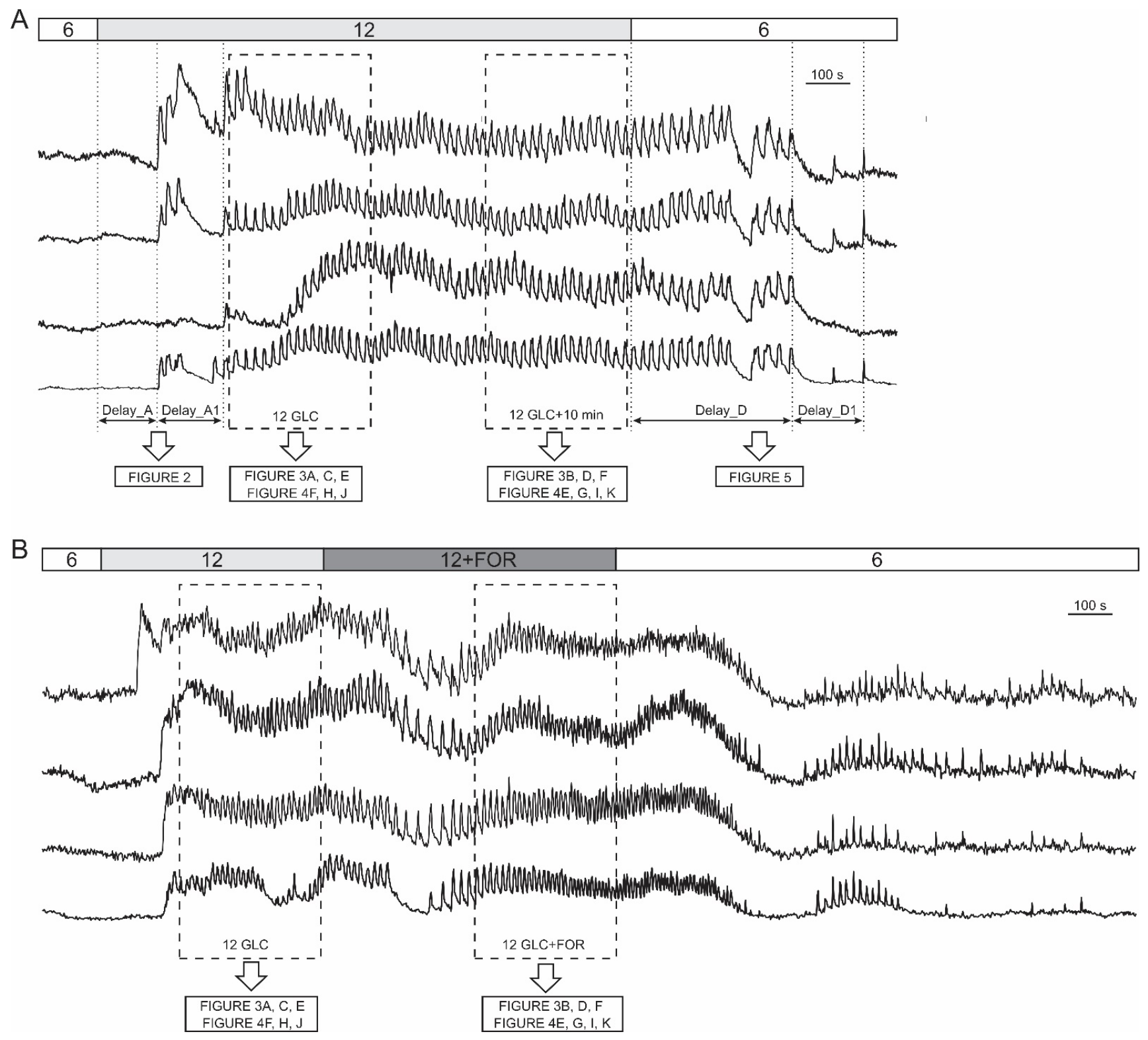

Figure 1: A typical beta cell response to glucose and forskolin. (A) $12 \mathrm{mM}$ glucose induced a transient increase in $\left[\mathrm{Ca}^{2+}\right]_{\mathrm{IC}}$, followed by $\left[\mathrm{Ca}^{2+}\right]_{\mathrm{IC}}$ oscillations during the plateau phase that ceased after stimulus withdrawal. Responses of 4 cells from the same islet are shown. Activation (Delay_A) and deactivation (Delay_D ) delays were defined as indicated in the figure; (B) $\left[\mathrm{Ca}^{2+}\right]_{I C}$ activity after addition of $10 \mu \mathrm{M}$ forskolin. Rectangles indicate intervals used in subsequent analysis of the plateau phase, the results of which are shown in indicated figures. Note that the prolonged stimulation with glucose only (A) served as a control for possible time effects, since forskolin was added to glucose after a stable plateau was achieved in response to glucose (B).

\subsection{The effect of forskolin and the role of Epac2A in activation of beta cells}

Beta cells were inactive in $6 \mathrm{mM}$ glucose in both WT and Epac2A KO mice (data not shown). We tested whether cAMP activation produced a shift in glucose sensitivity, and whether this effect was Epac2A-mediated (Figure 2 and Figure S1). $10 \mu \mathrm{M}$ forskolin added to $6 \mathrm{mM}$ glucose activated beta cells in a qualitatively similar manner as $12 \mathrm{mM}$ glucose. In quantitative terms, the delays between the stimulus onset and the activation of cells after the forskolin stimulus were smaller in KO mice (243 s vs. 693 s, delay_A). 
Surprisingly, the absence of Epac2A affected the activation properties in a similar manner even during stimulation with glucose only, as the activation delays were shorter in Epac2A KO mice (112 s vs. 168 s, Figure 2), suggesting a possible inhibitory role of Epac2A during the activation phase at both basal and strongly stimulated cAMP conditions.

We have shown previously that the glucose activation of beta cells was relatively heterogeneous (Figure 1), and that the differences in activation delays were strongly glucose-dependent [85]. In this vein, we assessed heterogeneity during activation by calculating delays of every cell relative to the first-responding cell in an islet (i.e., any-cell-first-responder delays, delay_A1, Figure 2B). The lack of Epac2A increased the any-cell-first-responder delay after stimulation with $12 \mathrm{mM}$ glucose by $26 \%$ (48 s in $\mathrm{KO}$ vs. $35 \mathrm{~s}$ in WT mice), in contrast to a decrease by $36 \%$ after stimulation with forskolin plus $6 \mathrm{mM}$ glucose (178 s in KO vs. $278 \mathrm{~s}$ in WT mice). Importantly, accounting for the inter-islet differences and the shorter activation in Epac2A $\mathrm{KO}$ mice by normalizing the data with the respective islet median delays (Figure 2C), the Epac2A deletion increased activation heterogeneity after stimulation with $12 \mathrm{mM}$ glucose $(0.47$ in $\mathrm{KO}$ and 0.21 in WT mice) and did not have a significant effect after stimulation with forskolin plus $6 \mathrm{mM}$ glucose. In sum, Epac2A seems to contribute to a less heterogeneous activation during stimulation with glucose.

A

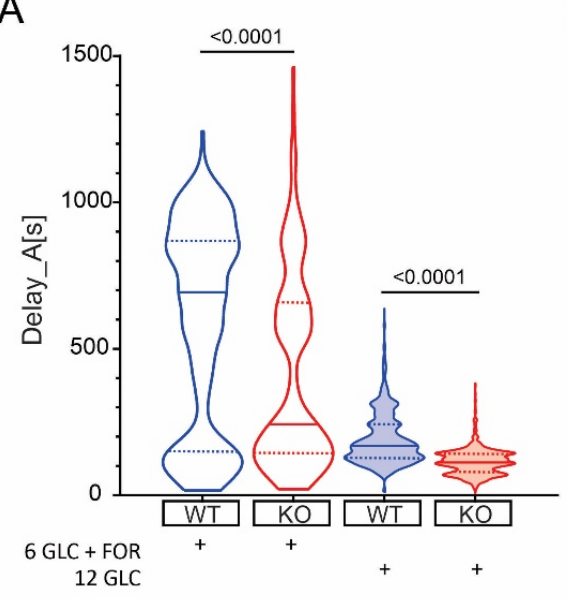

B

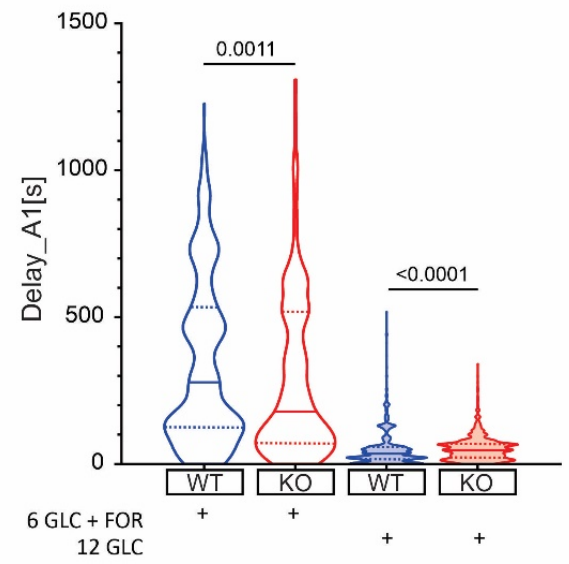

C

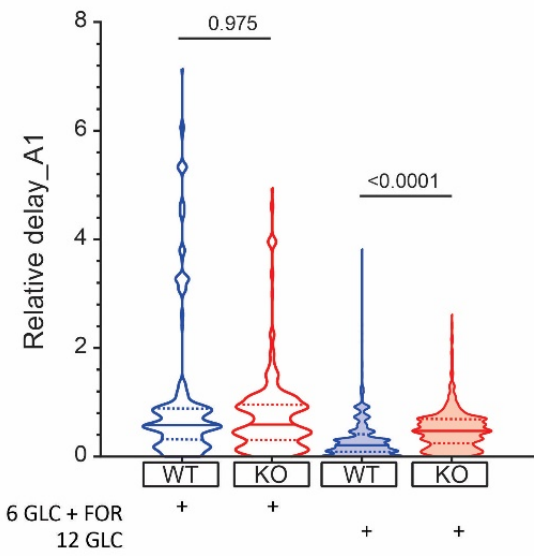

Figure 2: The effect of forskolin and the role of Epac2A during activation of beta cells from WT and KO mice. (A) The activation delays (Delay_A) after stimulation with either $6 \mathrm{mM}$ glucose $+10 \mu \mathrm{M}$ forskolin or $12 \mathrm{mM}$ glucose in WT and Epac2A KO mice. Note that the $6 \mathrm{mM}$ glucose failed to elicit a response in beta cells. $1^{\text {st }}$ quartile/median/3 $3^{\text {rd }}$ quartile (Q1/M/Q3, in seconds): $151 / 693 / 868$ (6 mM glucose $+10 \mu \mathrm{M}$ forskolin in WTs), 144/243/659 (6 mM glucose $+10 \mu \mathrm{M}$ forskolin in KOs), 127 /168/243 (12 $\mathrm{mM}$ glucose in WTs), and 81/112/142 (12 $\mathrm{mM}$ glucose in KOs); (B) The any-cell-first-responder delays after stimulation with either $6 \mathrm{mM}$ glucose $+10 \mu \mathrm{m}$ forskolin or 12 $\mathrm{mM}$ glucose in WT and Epac2A KO mice. Q1/M/Q3 (in seconds): 126/278/533 (6 mM glucose + 10 $\mu \mathrm{M}$ forskolin in WTs), 70/178/518 (6 mM glucose $+10 \mu \mathrm{M}$ forskolin in KOs), 17/35/58 (12 mM glucose in WTs), and 22/48/69 (12 mM glucose in KOs); (C) Relative any-cell-first-responder delays after stimulation with either $6 \mathrm{mM}$ glucose $+10 \mu \mathrm{m}$ forskolin or $12 \mathrm{mM}$ glucose. Q1/M/Q3: 0.32/0.58/0.90 (6 mM glucose $+10 \mu \mathrm{M}$ forskolin in WTs), 0.31/0.59/0.95 (6 mM glucose $+10 \mu \mathrm{M}$ forskolin in KOs), 0.009/0.21/0.40 (12 mM glucose in WTs), and 0.24/0.47/0.69 (12 mM glucose in $\mathrm{KO})$. Data pooled from the following number of cells/islets: $388 / 6(6 \mathrm{mM}$ glucose $+10 \mu \mathrm{M}$ forskolin in WTs), 428/8 (6 mM glucose + $10 \mu \mathrm{M}$ forskolin in KOs), 1373/24 (12 mM glucose in WTs), 1375/23 (12 mM glucose in KOs). Data were analyzed using Mann-Whitney U test, p values are indicated on graphs. 
We further explored the effect of cAMP activation and the specific role of Epac2A during the plateau phase by analyzing the classical and network functional parameters.

\subsubsection{Classical Functional Parameters}

$12 \mathrm{mM}$ glucose evoked repetitive fast $\left[\mathrm{Ca}^{2+}\right]$ Ic oscillations (Figure 1). Relative active time (AT) of a cell (defined as the percentage of oscillatory activity that the cells spent at a $\left[\mathrm{Ca}^{2+}\right.$ Ic $>50 \%$ of the oscillation amplitude, was $41 \%$ at a frequency of $0.033 \mathrm{~Hz}$ and an oscillation duration of $10.7 \mathrm{~s}$ (Figure 3A, C and E). Epac2A deletion increased the AT by $12 \%(\mathrm{AT}=46 \%)$, by increasing both oscillation duration (11.7 s) and frequency (0.039 $\mathrm{Hz})$.

Next, we tested the effect of pharmacological activation of AC. In WT mice, $10 \mu \mathrm{M}$ forskolin added to the stimulatory $12 \mathrm{mM}$ glucose increased the AT by $28 \%$ (from $43 \%$ to $55 \%$, Figure 3F). Interestingly, there was a considerable decrease in oscillation duration by $30 \%$ (8.5 s vs. 12.1 s, Figure 3D), but AT nevertheless increased due to a large increase in frequency by $75 \%(0.058 \mathrm{~Hz}$ vs. $0.033 \mathrm{~Hz}$, Figure 3B). In Epac2A KO mice the frequency also increased, oscillation duration decreased, and the active time increased to a similar extent and a similar absolute value as in WT mice (increase by $17 \%$, AT = 55 \% vs. $47 \%$, Figure $3 \mathrm{~F}$ ).

These results seem to suggest that the absence of Epac2A brings about a small but significant increase in active time during the response to $12 \mathrm{mM}$ glucose and that a pharmacological elevation of cAMP increases the active time through a large increase in oscillation frequency despite a concomitant decrease in oscillation duration, and that this modulation of $\left[\mathrm{Ca}^{2+}\right]_{\mathrm{IC}}$ oscillations is preserved in Epac2A $\mathrm{KO}$ mice and thus probably largely Epac2A-independent. 
A

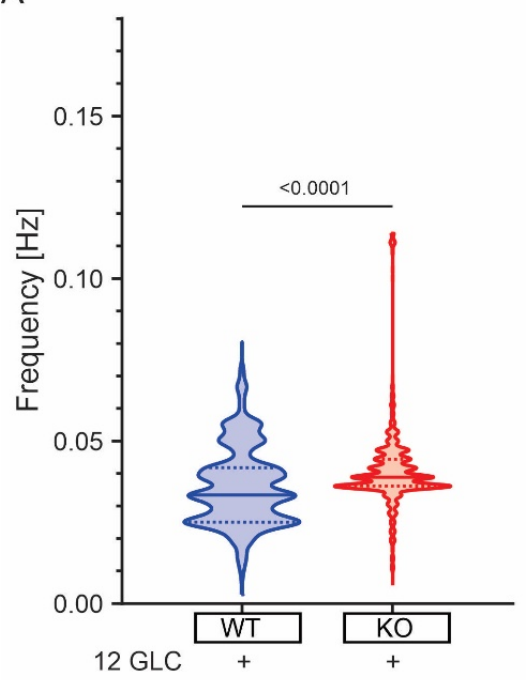

C

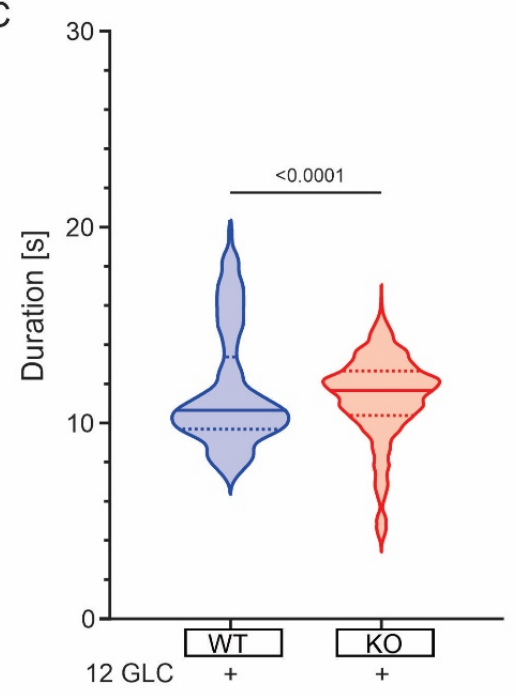

E

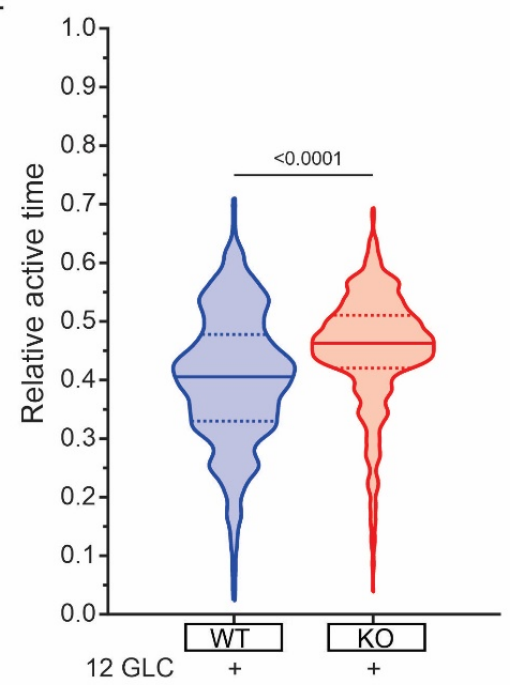

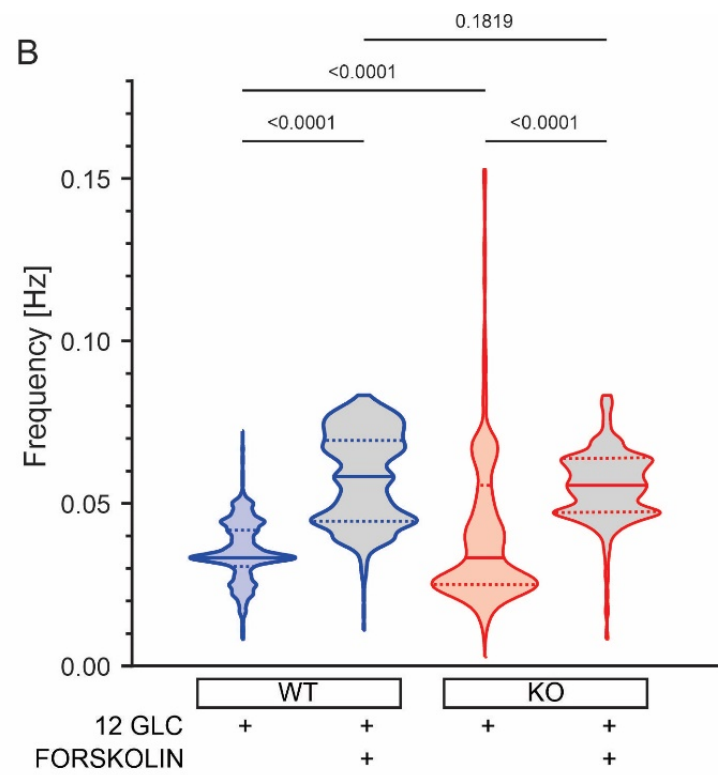

D

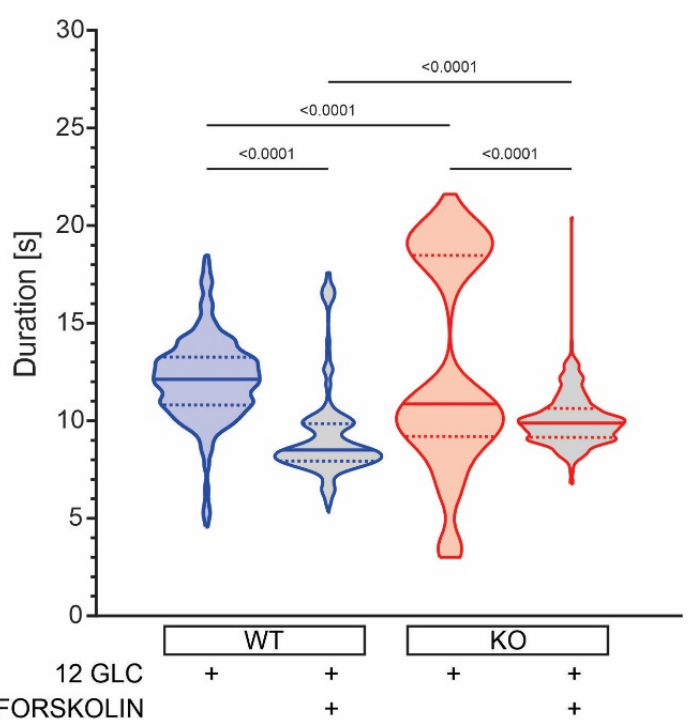

F

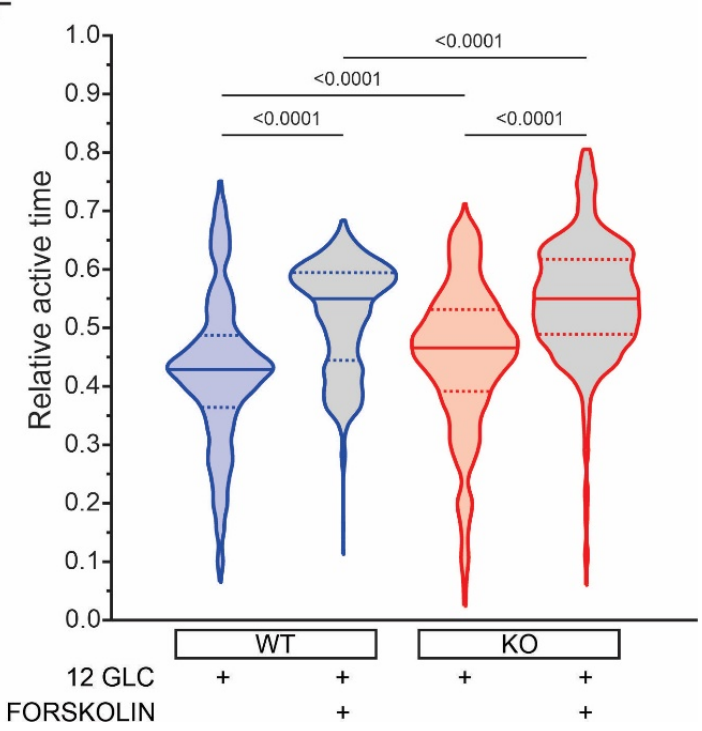


Figure 3: The effect of forskolin and the role of Epac2A during the plateau phase of response to glucose. (A) The oscillation frequency after stimulation with $12 \mathrm{mM}$ glucose. $1^{\text {st }}$ quartile $/$ median $/ 3^{\text {rd }}$ quartile (Q1/M/Q3) in Hz: 0.025/0.033/0.042 (in WTs) and 0.036/0.039/0.044 (in KOs); (B) The oscillation frequency after either prolonged stimulation with $12 \mathrm{mM}$ or addition of $10 \mu \mathrm{m}$ forskolin. Q1/M/Q3 in Hz: 0.031/0.033/0.042 (12 mM glucose in WTs), 0.045/0.058/0.069 (12 mM glucose + 10 $\mu \mathrm{M}$ forskolin in WTs), 0.025/0.033/0.056 (12 mM glucose in KOs) and 0.047/0.056/0.064 (12 mM glucose $+10 \mu \mathrm{M}$ forskolin in KOs); (C) The oscillation duration after stimulation with $12 \mathrm{mM}$ glucose. Q1/M/Q3 in seconds: 9.7/10.7/13.4 (in WTs) and 10.4/11.7/12.7 (in KOs); (D) The oscillation duration after either prolonged stimulation with $12 \mathrm{mM}$ or addition of $10 \mu \mathrm{m}$ forskolin. Q1/M/Q3 in seconds: 10.8/12.1/13.3 (12 mM glucose in WTs), 7.9/8.5/9.9 (12 mM glucose $+10 \mu \mathrm{M}$ forskolin in WTs), 9.2/10.9/18.5 (12 mM glucose in KOs), and 9.2/9.9/10.6 (12 mM glucose $+10 \mu \mathrm{M}$ forskolin in $\mathrm{KOs}$ ); (E) The relative active time after stimulation with $12 \mathrm{mM}$ glucose. Q1/M/Q3: 0.33/0.41/0.48 (in WTs) and 0.42/0.46/0.51 (in KOs); (F) The relative active time after either prolonged stimulation with $12 \mathrm{mM}$ or addition of $10 \mu \mathrm{m}$ forskolin. Q1/M/Q3: 0.36/0.43/0.49 (12 mM glucose in WTs), 0.44/0.55/0.59 (12 mM glucose $+10 \mu \mathrm{M}$ forskolin in WTs), 0.39/0.47/0.53 (12 mM glucose in KOs) and $0.49 / 0.55 / 0.62$ (12 mM glucose $+10 \mu \mathrm{M}$ forskolin in KOs). Data pooled from the following number of cells/islets: 687/11 (12 mM glucose in WTs), 656/11 (12 mM glucose $+10 \mu \mathrm{M}$ forskolin in WTs), 548/7 (12 mM glucose in KOs), and 631/9 (12 mM glucose + $10 \mu \mathrm{M}$ forskolin in KOs). Data were analyzed using Mann-Whitney U test (for 2 samples) or one-way ANOVA on ranks (Kruskal-Wallis test) followed by Dunn's multiple comparisons test for more than 2 samples), p values are indicated on graphs.

\subsubsection{Functional Network Parameters}

To characterize the collective beta cell $\left[\mathrm{Ca}^{2+}\right] \mathrm{Ic}$ activity, we constructed functional connectivity networks, as described in the Methods section. First, we present characteristic beta cell networks in islets from WT and Epac2A KO mice subjected to $12 \mathrm{mM}$ glucose stimulation only (Figures $4 \mathrm{~A}$ and $4 \mathrm{C}$ ) and in islets from both types of mice which were subsequently stimulated with $10 \mu \mathrm{M}$ forskolin (Figures $4 \mathrm{~B}$ and $4 \mathrm{D}$ ). Connectivity maps are presented separately for all four scenarios. After prolonged stimulation with 12 $\mathrm{mM}$ glucose only, the networks became much sparser in both WT and KO mice. In contrast, in the second protocol where $10 \mu \mathrm{M}$ forskolin was added to $12 \mathrm{mM}$ glucose, the networks remained integral, and the number of connections stayed approximately the same. These qualitative observations in the exemplary islets indicate that increasing cytosolic cAMP concentrations rather profoundly affected the collective beta cell behavior by preventing a decline in or even increasing intercellular connectivity, probably to a comparable extent in both types of mice.

To gain a more general and quantitative insight, we show in Figures 4E-K different metrics of synchronous beta cell dynamics and network parameters pooled from all islets. We first present the average node degrees, i.e., the average number of functional connections. Since we used an adaptive thresholding approach to set the average degree in the first part in the plateau phase to $\langle k>=8$ in all islets, we show only the values in the second interval. Results in Figure 4E reveal that in both WT and KO mice the average node degree was profoundly lower (median $k \approx 2$ ) after prolonged stimulation with $12 \mathrm{mM}$ glucose only. In the stimulation protocol with forskolin, the node degree in the second part of the plateau phase was on average higher in both types of mice when compared to stimulation with glucose only, with median values $k \approx 10$ and $k \approx 5$ for the islets from WT and $\mathrm{KO}$ mice, respectively. However, the difference between the control and the forskolin protocol was significant only for WT mice.

Next, we show the average correlation coefficients (Figures $4 \mathrm{~F}$ and G), modularity values (Figures $4 \mathrm{H}$ and I), and relative largest components (Figures $4 \mathrm{~J}$ and $\mathrm{K}$ ) of beta cell networks. For these metrics, we present first their absolute values in the first part of the plateau phase, separately for the islets from WT and $\mathrm{KO}$ mice (Figures $4 \mathrm{~F}, \mathrm{H}, \mathrm{J}$ ). None of these parameters were found to differ between the islets from the WT and KO mice, indicating that under stimulation with $12 \mathrm{mM}$ glucose only, Epac2A does not notably affect either the average synchronicity or the beta cell network's functional integrity and segregation patterns. We proceeded with examining the differences between the glucose stimulation only protocol and the forskolin protocol by comparing the parameters in the 
second part of the plateau phase. It turned out that in the islets which were subsequently stimulated with $10 \mu \mathrm{M}$ forskolin, the average correlation was higher when compared to prolonged $12 \mathrm{mM}$ glucose stimulation only. Furthermore, the networks were less segregated, and the level of functional integration was greater, as reflected by lower values of modularity (Figure 4I) and higher values of the relative largest component (Figure 4K), respectively. However, while all the above differences were significant in islets from WT mice, the effect of forskolin was less well-pronounced in islets from Epac2A KO mice and not statistically significant for any of the parameters, suggesting that Epac2A probably importantly contributes to the greater functional integration of cell networks during strong elevation of cAMP. To provide a more detailed insight, we additionally present in Figure S3 how the beta cell synchronization and different network parameters have changed between intervals, separately for each individual islet.
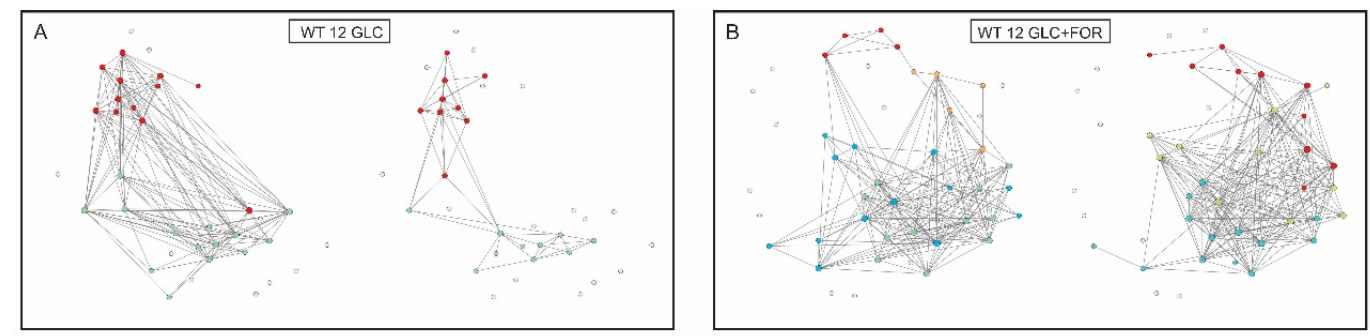
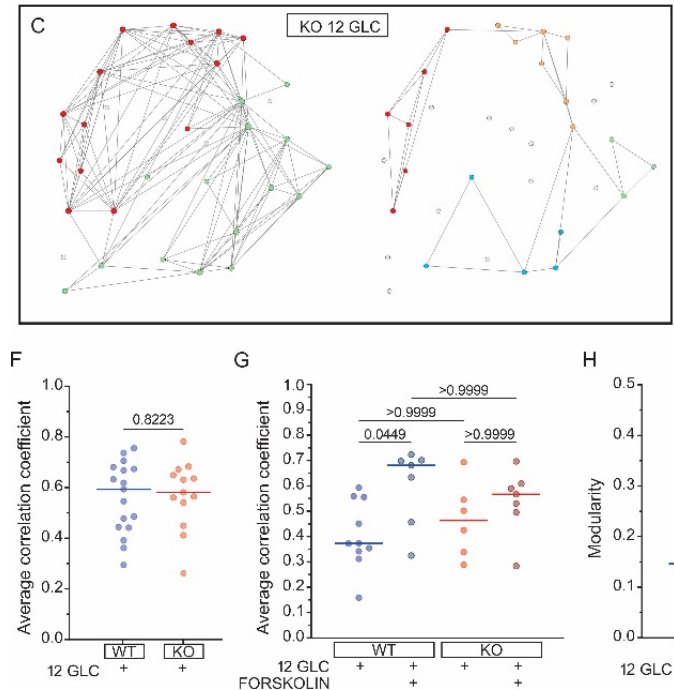

G

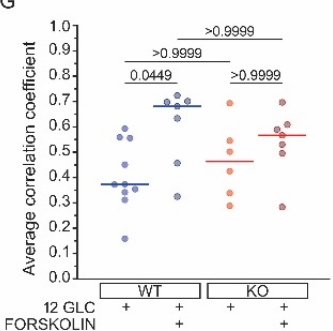

$\mathrm{H}$

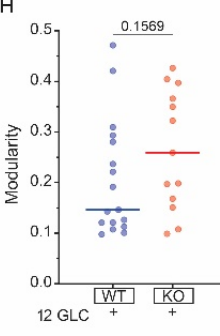

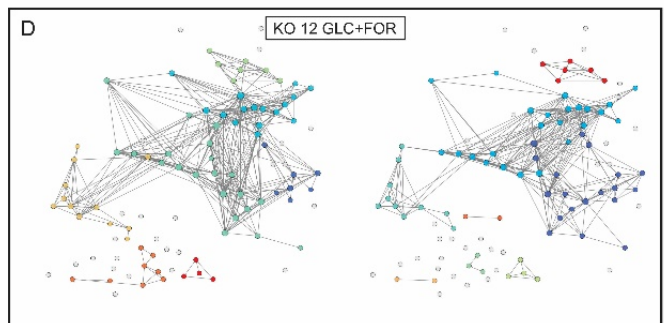

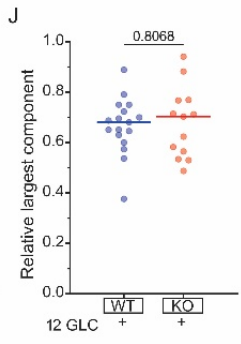

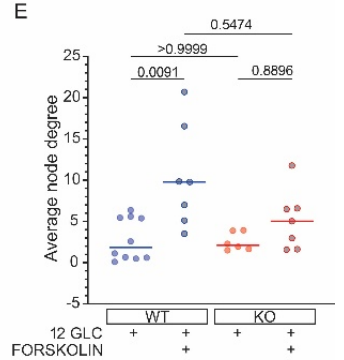

K

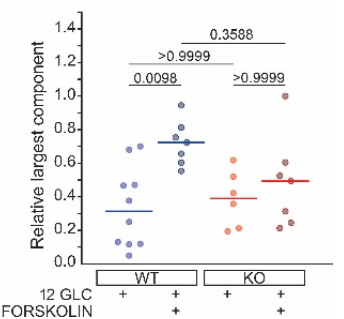

Figure 4: The effect of forskolin on functional beta cell connectivity networks and the role of Epac2A. (A-D) Characteristic functional network representations of islets from WT and Epac2A KO mice stimulated either with $12 \mathrm{mM}$ glucose or with $12 \mathrm{mM}$ glucose $+10 \mu \mathrm{M}$ forskolin. Nodes signify positions of beta cells within an islet, connections stand for functional associations in $\mathrm{Ca}^{2+} \mathrm{ac}^{-}$ tivity, and colors of cells denote different communities; (E-K) Synchronization and network metrics for the average pooled data from all islets in the given group: average node degree (e), average correlation coefficient $(F, G)$, modularity $(\mathbf{H}, \mathbf{I})$, relative largest component $(\mathbf{J}, \mathbf{K})$. In panels $(\mathbf{F}, \mathbf{H}, \mathbf{J})$ the values in the first part of the plateau phase (glucose only) are shown, whereas in panels (E, G, I, K) the values corresponding to the second part (either glucose only or glucose+forskolin) are presented. Individual dots represent the average values in individual islets, whereas the horizontal lines denote the median value. 
After cessation of stimulation with $12 \mathrm{mM}$ glucose, there was a delay before beta cells turned off (Figure 5A and Figure S4). This delay did not differ between WT and KO mice. Additional elevation of cAMP during stimulation with glucose (by forskolin) significantly prolonged the activity of cells (in WTs by $22 \%$, from 348 s to 426 s, Figure 5A). This prolongation was not Epac2A-dependent, as it was even significantly longer in $\mathrm{KO}$ mice (from 297 to 820s, Figure 5A). Thus, at least under conditions of high cAMP, Epac2A seems to restrict the activity of beta cells upon removal of the stimulus. In accordance with our previous studies, comparing deactivation delays between different cells (Figure 5B) demonstrated relatively large intercellular differences $[54,70,85]$. Elevation of cAMP by forskolin increased the first-cell-any-cell delays (in WTs from $87 \mathrm{~s}$ to $214 \mathrm{~s}$, Figure 5B). Although this effect of forskolin did not depend on Epac2A in absolute terms (214 $\mathrm{s}$ in WT and $210 \mathrm{~s}$ in $\mathrm{KO}$ mice, Figure 3B), taking into account the inter-islet variability of the median delays and the absolutely longer delays in KOs revealed that forskolin increased the relative heterogeneity only in WTs (from 0.26 to 0.51 , Figure 3C). On the other hand, this normalization also showed that the relative heterogeneity may be slightly more in KOs after stimulation with glucose only (0.21 vs. 0.34, Figure 3C).

Taken together, these results suggest that increasing cAMP increases beta cell activity not only by making the activation more likely and by increasing the active time during the plateau phase, but also by prolonging beta cell activity upon removal of the stimulus, extending their activity into an otherwise silent period. This effect of cAMP on deactivation seems to be Epac2A-independent and under normal conditions, Epac2A may even restrict this effect of cAMP. Elevated cAMP also made deactivation more heterogenous in absolute terms, but given the huge prolongation of deactivation in KOs, this increase in heterogeneity was relatively larger in WTs. On the other hand, after stimulation with glucose only, the deactivation was slightly more heterogenous in KOs (in relative terms).
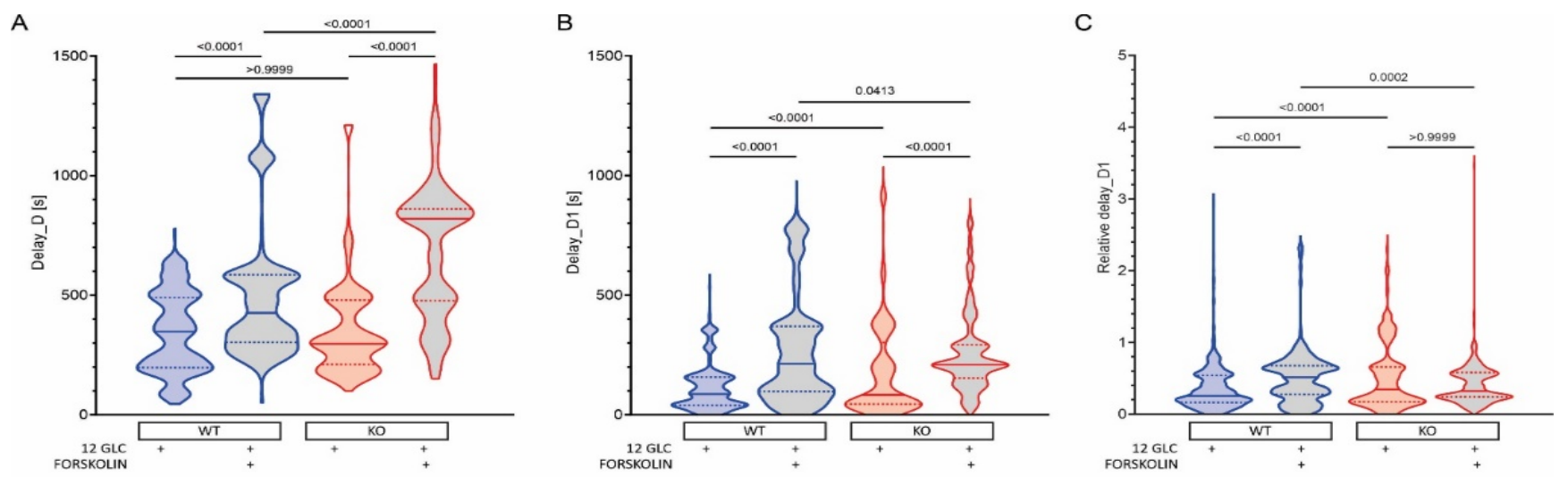

Figure 5: The effect of forskolin and the role of Epac2A during deactivation of beta cells from WT and $\mathrm{KO}$ mice. (A) The deactivation delays after cessation of stimulation with $12 \mathrm{mM}$ glucose in the presence or absence of $10 \mu \mathrm{m}$ forskolin. $1^{\text {st }}$ quartile/median/3rd quartile (Q1/M/Q3), in seconds): 197/348/490 (12 mM glucose in WTs), 303/426/586 (12 mM glucose $+10 \mu \mathrm{M}$ forskolin in WTs), 211/297/479 (12 mM glucose in KOs), and 477/820/861 (12 mM glucose + $10 \mu \mathrm{M}$ forskolin in KOs); (B) The deactivation delays of cells after $1^{\text {st }}$ deactivated cell after cessation of stimulation with 12 $\mathrm{mM}$ glucose in the presence or absence of $10 \mu \mathrm{m}$ forskolin. Q1/M/Q3 (in seconds): 39/87/158 (12 $\mathrm{mM}$ glucose in WTs), 97/214/370 (12 mM glucose $+10 \mu \mathrm{M}$ forskolin in WTs), 45/83/303 (12 mM glucose in KOs), and 153/210/293 (12 mM glucose + $10 \mu \mathrm{M}$ forskolin in KOs); (C) Relative deactivation delays of cells after $1^{\text {st }}$ deactivated cell after cessation of stimulation with $12 \mathrm{mM}$ glucose in the presence or absence of $10 \mu \mathrm{m}$ forskolin. Q1/M/Q3 (in seconds): 0.16/0.26/0.54 (12 mM glucose in WTs), $0.28 / 0.51 / 0.68$ (12 mM glucose $+10 \mu \mathrm{M}$ forskolin in WTs), 0.17/0.34/0.66 (12 $\mathrm{mM}$ glucose in KOs), and 0.24/0.32/0.58 (12 mM glucose $+10 \mu \mathrm{M}$ forskolin in KOs). Data pooled from the following number of cells/islets: 678/13 (12 mM glucose in WTs), 640/10 (12 mM glucose $+10 \mu \mathrm{M}$ forskolin in $\mathrm{WT}), 567 / 10$ (12 mM glucose in KOs), 422/7 (12 mM glucose + $10 \mu \mathrm{M}$ forskolin in KOs). Data were 
analyzed using one-way ANOVA on ranks (Kruskal-Wallis test) followed by Dunn's multiple comparisons test, $\mathrm{p}$ values are indicated on graphs.

\section{Discussion}

The principal aims of this study were to describe in detail the effects of elevated cAMP on $\left[\mathrm{Ca}^{2+}\right] \mathrm{Ic}$ oscillations in beta cells during activation, activity, and deactivation, both in classical physiological terms and by using network analyses, and to determine the role of Epac2A in the above effects.

We showed previously that pancreatic beta cells within acute mouse pancreas tissue slices are typically silent in $6 \mathrm{mM}$ glucose and respond to stimulatory glucose concentrations above $7 \mathrm{mM}$ with a transient increase of $\left[\mathrm{Ca}^{2+}\right]$ Ic followed by fast $\left[\mathrm{Ca}^{2+}\right]_{\mathrm{Ic}}$ oscillations $[54,65,85]$. In the present work, we demonstrated that beta cells from both Epac2A KO and WT mice responded to the otherwise sub-stimulatory glucose $(6 \mathrm{mM})$ after increasing cAMP by the diterpene forskolin. This indicates that a rise in cAMP due to AC activation can affect $\left[\mathrm{Ca}^{2+}\right] \mathrm{Ic}$, probably in a PKA-dependent and Epac2A-independent manner, as already described before $[32,34,86]$. Several studies demonstrated that this could involve an increased cytosolic ATP/ADP ratio, either by accelerated ATP synthesis, decreased ATP degradation, or by redistribution of ATP between different intracellular pools [87], decreased KATP conductance [12], inhibition of $\mathrm{K}^{+}$currents through voltage-dependent KV1.4 channels $[34,86]$, enhancement of $\mathrm{Ca}^{2+}$ signals through VDCC and/or $\mathrm{Ca}^{2+}$ mobilization from internal stores via RyR or IP $3 \mathrm{R}$ [13-16]. Although forskolin is a potent $\mathrm{AC}$ activator that successfully evoked oscillations of $\left[\mathrm{Ca}^{2+}\right] \mathrm{Ic}$ in $6 \mathrm{mM}$ glucose, the effect of forskolin in $6 \mathrm{mM}$ glucose seems to be weaker compared to the stimulation with $12 \mathrm{mM}$ glucose, since we observed a much shorter activation delay in $12 \mathrm{mM}$ glucose. This supports previously published data showing progressively shorter activation delay with increasing glucose concentrations $[54,65,85,88]$, a phenomenon most probably resulting from the amount of metabolized glucose needed to activate beta cells [89]. Furthermore, while in $12 \mathrm{mM}$ glucose most beta cells within an islet responded to stimulation, when stimulated with $6 \mathrm{mM}$ glucose + forskolin, only a minority of beta cells became active (data not shown), demonstrating large differences in their metabolic activity and therefore their sensitivity to glucose also under conditions of elevated cAMP. Since in our protocol beta cells were exposed to forskolin only for $10 \mathrm{~min}$, we wish to point out the possibility that the majority of beta cells within an islet could eventually be recruited and would respond to prolonged stimulation with forskolin, as seen during stimulation with lower stimulatory concentrations of glucose [85]. Interestingly, beta cells from Epac2A KO mice responded to both stimulation protocols with a shorter activation delay compared to their WT littermates (Figure 2). As mentioned before, cAMP can affect $\left[\mathrm{Ca}^{2+}\right] \mathrm{IC}$ in a PKA-dependent $[32,34,86]$ or an Epac2A-dependent manner [13-16,90]. In Epac2A KO cells, all of the available cAMP produced either by forskolin-enhanced AC activity in sub-stimulatory glucose conditions or endogenously synthesized in beta cells after a high glucose load, will act only through PKA-dependent pathways, increasing for instance the L-type VDCC activity after phosphorylation with PKA [13,14,91]. Our results point to the possibility that the role of Epac2A may be at least partly inhibitory during activation, that in Epac2A KO mice, there is a compensatory upregulation of the stimulatory PKA-dependent mechanisms, or a combination of both.

The activation delays among islets as well as among beta cells within the same islet were very heterogeneous, as observed from the delays between the first-responding cell and the others from the same islet in both protocols (Figure 2 and Supplemental Figure 1). However, the possibility exists that the observed heterogeneity during activation is just an experimental artifact due to the dynamics of glucose increase in different parts of the islet in the perifusion chamber, but we demonstrated before that beta cells are exposed to practically identical extracellular glucose concentrations almost instantaneously [54]. Therefore, the heterogeneity in activation delays among the cells from the same islet 
must be due to their intrinsic heterogeneity at several levels of the glucose response process, as already discussed above. The majority of previous studies confirm this, showing at least some degree of heterogeneity during activation [77,85,89,92-97]. Here we showed that in both WT and KO cells, the heterogeneity of activation delays decreased with faster activation, enabling beta cells a more homogeneous response to a stronger stimulation (i.e., $12 \mathrm{mM}$ glucose vs. $6 \mathrm{mM}$ glucose $+10 \mu \mathrm{M}$ forskolin). Interestingly, the relative heterogeneity of activation delays was higher in beta cells from Epac2A $\mathrm{KO}$ mice in the high glucose regime (Figure 2C), suggesting the involvement of Epac2A in the coordination of activation under a high glucose load. The latter could be mediated through Cx36 gap junction coupling in an Epac2A-dependent manner to overcome the extensive intrinsic heterogeneity present in beta cells and to ensure a more coordinated response to glucose $[77,80]$. This view is also consistent with the above finding that the responses are faster in Epac2A KO mice, since in more weakly coupled syncytia, the intrinsically more sensitive cells can escape the inhibition from less responsive cells $[65,98,99]$. Most importantly, our findings regarding network and deactivation properties also argue for a role of Epac2A in intercellular coupling (see below) and are consistent with another recent report [61], but clearly deserve to be explored further in the future.

Next, the plateau phase of response after stimulation with high glucose consists of repetitive fast $\left[\mathrm{Ca}^{2+}\right]$ Ic oscillations that reflect bursts of membrane potential depolarizations $[57,93,100,101]$. In our hands, the absence of Epac2A did not prevent the strong cAMP-mediated increase in frequency of oscillations and active time (Figure 3). A similar effect was observed for oscillations of membrane potential in GLP-1-activated cells under high glucose conditions [12,102]. Interestingly, the cells that were previously less active increased their oscillation frequency the most, while the duration of oscillations decreased slightly in the majority of cells. This response to forskolin clearly shows that the activation of the neurohormonal amplifying pathway through cAMP involves different molecular mechanisms compared to glucose stimulation. Increasing the glucose load above $12 \mathrm{mM}$ glucose namely results in increased oscillation duration at the cost of reduced oscillation frequency [85]. The potentiation of $\left[\mathrm{Ca}^{2+}\right] \mathrm{IC}$ oscillations under high cAMP levels is probably exerted independently of KATP channels, since GLP-1 is able to increase insulin secretion also in Kir6.2 KO mice that lack functional KATP channels [103] and probably involves increased $\mathrm{Ca}^{2+}$ influx through L-type VDCCs, phosphorylated by PKA [35] as well as PKA- and Epac2A-dependent mobilization of $\mathrm{Ca}^{2+}$ from internal stores $[13-16,18]$. In addition to the possible direct effects of cAMP on $\left[\mathrm{Ca}^{2+}\right] \mathrm{IC}$, there is evidence that the amplifying effect of cAMP could be explained by an increased gap junctional conductance between beta cells [75]. In beta cell syncytium, electrical coupling through Cx36 plays a crucial role in regulating coordinated glucose-induced $\mathrm{Ca}^{2+}$ oscillations, thereby determining the dynamics of insulin secretion $[80,104,105]$. In the present paper, we demonstrated that under stimulatory glucose levels, electrical coupling results in well- coordinated $\mathrm{Ca}^{2+}$ oscillations, but prolonged exposure to glucose causes an Epac2A-independent beta cell desynchronization, lower network integrity and higher segregation (Figure 4). On the other hand, elevated cAMP is able to prevent this decline in network function, but in an at least partly Epac2A-dependent manner, since in Epac2A $\mathrm{KO}$ mice, the improvement in network parameters was only partial. Disrupted cellular communication was described before in metabolically overloaded cells [61,73,77], while the GLP-1R agonist, Exendin-4, increased Cx36 coupling and improved $\mathrm{Ca}^{2+}$ oscillation coordination [61]. Several mechanisms have been proposed to explain how cAMP regulates Cx36, either by changing Cx36 gene expression, increasing Cx36 coupling, or by changing distribution of Cx36 on the cell membrane $[80,106,107]$. In the retina, cAMP has been shown to regulate gap junction coupling in a PKA-dependent manner [108], with no effect on trafficking or changing the distribution of Cx36 on the plasma membrane [81,109], while in myocardial cells, PKA is responsible for opening of Cx36 [110]. On the other hand, in neurons, regulation of Cx36 is Epac2A-mediated [111]. In pancreatic beta cells, both PKA and Epac2A seem to be responsible for Cx36 regulation. PKA was proposed as a channel gating regulator, while Epac2A probably influences $\mathrm{C} \times 36$ coupling via 
slower mechanisms, such as trafficking, assembly, or turnover [61], similarly as in rat myocardial cells $[82,83]$. Overall, our data suggest that the presence of Epac2A is not critical for basal beta cell functional network integrity upon stimulation with glucose, but seems to importantly contribute to the positive effects elicited by increased cAMP.

After cessation of stimulation, the oscillatory activity in beta cells gradually stops, and $\left[\mathrm{Ca}^{2+}\right]$ Ic returns to baseline. Proper deactivation is especially important to prevent hypoglycemia [98,112]. Like activation, the deactivation phase is also glucose-dependent [85]. After decreasing glucose from $12 \mathrm{mM}$ to the sub-stimulatory level $(6 \mathrm{mM})$, beta cells deactivated with 2-3 times greater time lags compared to the activation phase, with no differences between WT and Epac2A KO mice (Figure 5). Again, considerable heterogeneity was observed among cells, which is in accordance with previously published studies $[54,70,85]$. When beta cells were additionally stimulated by forskolin, the deactivation delay was prolonged significantly, similarly to what can be seen under an extremely high glucose load [85], and this prolongation was especially pronounced in cells lacking Epac2A. Longer and more heterogenous deactivation delays probably indicate a greater degree of activation during the preceding stimulation period, not only through the triggering pathway, but also through the neurohormonal amplifying pathway and increased cAMP levels. It is reasonable to speculate that following strong stimulation every beta cell will need longer to decrease the concentration of the triggering and amplifying secondary messengers below the stimulatory level. To speculate even further, we believe that slight changes in Cx36 coupling in Epac2A KO mice could at least partly account for the faster and more heterogeneous activation, decreased responsiveness of network parameters to CAMP, and also the longer deactivation delay. This hypothesis is a good starting point for future work that should also concentrate on the relevance of these findings in mouse models of diabetes mellitus and for the human islets.

\section{Conclusions}

To conclude, beta cell collectives activated in response to otherwise sub-stimulatory glucose concentration after elevating cAMP by forskolin. Beta cells from Epac2A KO mice responded faster than beta cells from WT littermates, both to high glucose and forskolin added to low glucose.

During the plateau phase, elevating cAMP during stimulation with high glucose resulted in increased oscillation frequency and relative active time, with well-coordinated activity among beta cells and this response to cAMP did not depend on Epac2A. Prolonged exposure to glucose caused Epac2A-independent beta cell desynchronization, lower network integrity, and higher segregation, while activation of the neurohormonal amplifying pathway prevented this decline in network function in an at least partly Epac2A-dependent manner.

In the end, following stimulation with high glucose and increased cAMP, beta cells deactivated more slowly and the prolongation of activity into the otherwise already silent period was especially well pronounced in beta cells from Epac2A KO mice.

Supplementary Materials: The following are available online at www.mdpi.com/xxx/s1, Figure S1: title, Figure S2:title, Figure S3: title, Figure S4: title

Author Contributions: Conceptualization, M.S.K., A.S., and M.S.R.; methodology, M.S.K., J.D., M.G. and A.S.; software, J.D. and M.G..; validation, M.S.K. and A.S.; formal analysis, M.S.K., J.D. and M.G.; investigation, M.S.K., J.D., L.K.B. and V.P.; resources, M.S.K., J.D. and M.G.; data curation, M.S.K., J.D. and M.G.; writing-original draft preparation, M.S.K., J.D., L.K.B., V.P., M.G. and A.S.; writing - review and editing, A.S. and M.S.K.; visualization, M.S.K. and M.G.; supervision, A.S. and M.S.R.; project administration, M.S.K., A.S. and M.S.R.; funding acquisition, A.S. and M.S.R. All authors have read and agreed to the published version of the manuscript. 
Funding: This research was funded by SLOVENIAN RESEARCH AGENCY, grant number P3-0396, I0-0029, N3-0048, N3-0133, and J3-9289.

Institutional Review Board Statement: The study was conducted according to the guidelines of the Declaration of Helsinki, and approved by the Institutional Review Board of VETERINARY ADMINITRATION OF THE REPUBLIC OF SLOVENIA (U34401-61/2009/2 29. 10. 2009) and by ADMINISTRATION OF THE REPUBLIC OF SLOVENIA FOR FOOD SAFETY, VETERINARY SECTOR AND PLANT PROTECTION (U34401-12/2015/3 1. 4. 2015)."

Data Availability Statement: Data available upon request.

Acknowledgments: We thank Rudi Mlakar for his excellent technical assistance. We also thank Professor Susumo Seino, Kobe University Graduate School of Medicine, Kobe, Japan and Professor Martina Schmidt, University of Groningen, Groningen, the Netherlands, for providing Epac2A KO mice to establish our colony.

Conflicts of Interest: The authors declare no conflict of interest.

\section{References}

1. IDF Diabetes Atlas, 9th ed.; International Diabetes Federation 2019.

2. Weyer, C.; Bogardus, C.; Mott, D.M.; Pratley, R.E. The natural history of insulin secretory dysfunction and insulin resistance in the pathogenesis of type 2 diabetes mellitus. J. Clin. Invest. 1999, 104, 787-794, doi:10.1172/jci7231.

3. Szecowka, J.; Grill, V.; Sandberg, E.; Efendic, S. Effect of GIP on the secretion of insulin and somatostatin and the accumulation of cyclic AMP in vitro in the rat. Acta Endocrinol (Copenh) 1982, 99, 416-421, doi:10.1530/acta.0.0990416.

4. Szecowka, J.; Lins, P.E.; Efendic, S. Effects of cholecystokinin, gastric inhibitory polypeptide, and secretin on insulin and glucagon secretion in rats. Endocrinology 1982, 110, 1268-1272, doi:10.1210/endo-110-4-1268.

5. Takeda, J.; Seino, Y.; Tanaka, K.; Fukumoto, H.; Kayano, T.; Takahashi, H.; Mitani, T.; Kurono, M.; Suzuki, T.; Tobe, T., et al. Sequence of an intestinal cDNA encoding human gastric inhibitory polypeptide precursor. Proceedings of the National Academy of Sciences of the United States of America 1987, 84, 7005-7008, doi:10.1073/pnas.84.20.7005.

6. Mayo, K.E.; Miller, L.J.; Bataille, D.; Dalle, S.; Goke, B.; Thorens, B.; Drucker, D.J. International Union of Pharmacology. XXXV. The glucagon receptor family. Pharmacol Rev 2003, 55, 167-194, doi:10.1124/pr.55.1.6.

7. Mortensen, K.; Christensen, L.L.; Holst, J.J.; Orskov, C. GLP-1 and GIP are colocalized in a subset of endocrine cells in the small intestine. Regul Pept 2003, 114, 189-196, doi:10.1016/s0167-0115(03)00125-3.

8. Roger, B.; Papin, J.; Vacher, P.; Raoux, M.; Mulot, A.; Dubois, M.; Kerr-Conte, J.; Voy, B.H.; Pattou, F.; Charpentier, G., et al. Adenylyl cyclase 8 is central to glucagon-like peptide 1 signalling and effects of chronically elevated glucose in rat and human pancreatic beta cells. Diabetologia 2011, 54, 390-402, doi:10.1007/s00125-010-1955-x.

9. Howell, S.L.; Jones, P.M.; Persaud, S.J. REGULATION OF INSULIN-SECRETION - THE ROLE OF 2ND-MESSENGERS. Diabetologia 1994, 37, S30-S35, doi:10.1007/bf00400823.

10. Takahashi, N.; Kishimoto, T.; Nemoto, T.; Kadowaki, T.; Kasai, H. Fusion Pore Dynamics and Insulin Granule Exocytosis in the Pancreatic Islet. Science 2002, 297, 1349-1352, doi:10.1126/science.1073806.

11. Henquin, J.C.; Nenquin, M. Activators of PKA and Epac distinctly influence insulin secretion and cytosolic Ca2+ in female mouse islets stimulated by glucose and tolbutamide. Endocrinology 2014, 155, 3274-3287, doi:10.1210/en.2014-1247.

12. Gromada, J.; Bokvist, K.; Ding, W.G.; Holst, J.J.; Nielsen, J.H.; Rorsman, P. Glucagon-like peptide 1 (7-36) amide stimulates exocytosis in human pancreatic beta-cells by both proximal and distal regulatory steps in stimulus-secretion coupling. Diabetes 1998, 47, 57-65, doi:10.2337/diab.47.1.57.

13. Ammala, C.; Ashcroft, F.M.; Rorsman, P. Calcium-independent potentiation of insulin release by cyclic AMP in single [beta]-cells. Nature 1993, 363, 356-358. 
14. Kanno, T.; Suga, S.; Wu, J.; Kimura, M.; Wakui, M. Intracellular cAMP potentiates voltage-dependent activation of L-type Ca2+ channels in rat islet beta-cells. Pflugers Archiv : European journal of physiology 1998, 435, 578-580, doi:10.1007/s004240050556.

15. Kang, G.; Chepurny, O.G.; Rindler, M.J.; Collis, L.; Chepurny, Z.; Li, W.-h.; Harbeck, M.; Roe, M.W.; Holz, G.G. A cAMP and $\mathrm{Ca} 2+$ coincidence detector in support of $\mathrm{Ca} 2+$-induced $\mathrm{Ca} 2+$ release in mouse pancreatic $\beta$ cells. The Journal of physiology 2005, 566, 173-188, doi:10.1113/jphysiol.2005.087510.

16. Chepurny, O.G.; Kelley, G.G.; Dzhura, I.; Leech, C.A.; Roe, M.W.; Dzhura, E.; Li, X.; Schwede, F.; Genieser, H.G.; Holz, G.G. PKA-dependent potentiation of glucose-stimulated insulin secretion by Epac activator 8-pCPT-2'-O-Me-cAMP-AM in human islets of Langerhans. American journal of physiology. Endocrinology and metabolism 2010, 298, E622-633, doi:10.1152/ajpendo.00630.2009.

17. Dyachok, O.; Gylfe, E. Ca2+-induced Ca2+ Release via Inositol 1,4,5-trisphosphate Receptors Is Amplified by Protein Kinase A and Triggers Exocytosis in Pancreatic $\hat{I}_{\iota}$-Cells. Journal of Biological Chemistry 2004, 279, 45455-45461, doi:10.1074/jbc.M407673200.

18. Dzhura, I.; Chepurny, O.G.; Kelley, G.G.; Leech, C.A.; Roe, M.W.; Dzhura, E.; Afshari, P.; Malik, S.; Rindler, M.J.; Xu, X., et al. Epac2-dependent mobilization of intracellular Ca2+ by glucagon-like peptide-1 receptor agonist exendin-4 is disrupted in $\beta$-cells of phospholipase C- $\varepsilon$ knockout mice. The Journal of physiology 2010, 588, 4871-4889, doi:10.1113/jphysiol.2010.198424.

19. Dzhura, I.; Chepurny, O.G.; Leech, C.A.; Roe, M.W.; Dzhura, E.; Xu, X.; Lu, Y.; Schwede, F.; Genieser, H.-G.; Smrcka, A.V., et al. Phospholipase C- $\varepsilon$ links Epac2 activation to the potentiation of glucose-stimulated insulin secretion from mouse islets of Langerhans. Islets 2011, 3, 121-128.

20. Skelin, M.; Rupnik, M. cAMP increases the sensitivity of exocytosis to Ca2+ primarily through protein kinase A in mouse pancreatic beta cells. Cell Calcium 2011, 49, 89-99, doi:10.1016/j.ceca.2010.12.005.

21. Skelin Klemen, M.; Dolenšek, J.; Slak Rupnik, M.; Stožer, A. The triggering pathway to insulin secretion: Functional similarities and differences between the human and the mouse $\beta$ cells and their translational relevance. Islets 2017, 9, 109-139, doi:10.1080/19382014.2017.1342022.

22. Seino, S.; Sugawara, K.; Yokoi, N.; Takahashi, H. beta-Cell signalling and insulin secretagogues: A path for improved diabetes therapy. Diabetes, obesity \& metabolism 2017, 19 Suppl 1, 22-29, doi:10.1111/dom.12995.

23. Ashcroft, F.M.; Ashcroft, S.J.H. Mechanism of insulin secretion. In Insulin: molecular biology to pathology, Ashcroft, F.M., Ashcroft, S.J.H., Eds. IRL Press at Oxford University Press: 1992; pp. 97-150.

24. Rorsman, P.; Renström, E. Insulin granule dynamics in pancreatic beta cells. Diabetologia 2003, 46, 1029-1045, doi:10.1007/s00125-003-1153-1.

25. Rorsman, P.; Ashcroft, F.M. Pancreatic $\beta$-Cell Electrical Activity and Insulin Secretion: Of Mice and Men. Physiological reviews 2018, 98, 117-214, doi:10.1152/physrev.00008.2017.

26. Dou, H.; Wang, C.; Wu, X.; Yao, L.; Zhang, X.; Teng, S.; Xu, H.; Liu, B.; Wu, Q.; Zhang, Q., et al. Calcium influx activates adenylyl cyclase 8 for sustained insulin secretion in rat pancreatic beta cells. Diabetologia 2015, 58, 324-333, doi:10.1007/s00125-014-3437-z.

27. Tengholm, A.; Gylfe, E. cAMP signalling in insulin and glucagon secretion. Diabetes, obesity $\mathcal{E}$ metabolism 2017, 19 Suppl 1, 42-53, doi:10.1111/dom.12993.

28. Trexler, A.J.; Taraska, J.W. Regulation of insulin exocytosis by calcium-dependent protein kinase C in beta cells. Cell Calcium 2017, 67, 1-10, doi:10.1016/j.ceca.2017.07.008.

29. Renström, E.; Eliasson, L.; Rorsman, P. Protein kinase A-dependent and -independent stimulation of exocytosis by cAMP in mouse pancreatic B-cells. The Journal of physiology 1997, 502, 105-118. 
30. Eliasson, L.; Ma, X.; Renstrom, E.; Barg, S.; Berggren, P.-O.; Galvanovskis, J.; Gromada, J.; Jing, X.; Lundquist, I.; Salehi, A., et al. SUR1 Regulates PKA-independent cAMP-induced Granule Priming in Mouse Pancreatic B-cells. J. Gen. Physiol. 2003, 121, 181-197, doi:10.1085/jgp.20028707.

31. Shibasaki, T.; Takahashi, H.; Miki, T.; Sunaga, Y.; Matsumura, K.; Yamanaka, M.; Zhang, C.; Tamamoto, A.; Satoh, T.; Miyazaki, J.-i., et al. Essential role of Epac2/Rap1 signaling in regulation of insulin granule dynamics by cAMP. Proceedings of the National Academy of Sciences 2007, 104, 19333-19338, doi:10.1073/pnas.0707054104.

32. Light, P.E.; Manning Fox, J.E.; Riedel, M.J.; Wheeler, M.B. Glucagon-like peptide-1 inhibits pancreatic ATP-sensitive potassium channels via a protein kinase A- and ADP-dependent mechanism. Mol Endocrinol 2002, 16, 2135-2144, doi:10.1210/me.2002-0084.

33. MacDonald, P.E.; Salapatek, A.M.F.; Wheeler, M.B. Temperature and redox state dependence of native Kv2.1 currents in rat pancreatic beta-cells. The Journal of physiology 2003, 546, 647-653, doi:10.1113/jphysiol.2002.035709.

34. Kim, S.J.; Choi, W.S.; Han, J.S.; Warnock, G.; Fedida, D.; McIntosh, C.H. A novel mechanism for the suppression of a voltage-gated potassium channel by glucose-dependent insulinotropic polypeptide: protein kinase A-dependent endocytosis. The Journal of biological chemistry 2005, 280, 28692-28700, doi:10.1074/jbc.M504913200.

35. Gromada, J.; Holst, J.J.; Rorsman, P. Cellular regulation of islet hormone secretion by the incretin hormone glucagon-like peptide 1. Pflügers Arch. 1998, 435, 583-594, doi:10.1007/s004240050558.

36. Wan, Q.F.; Dong, Y.; Yang, H.; Lou, X.; Ding, J.; Xu, T. Protein kinase activation increases insulin secretion by sensitizing the secretory machinery to Ca2+. J Gen Physiol 2004, 124, 653-662.

37. Dolensek, J.; Skelin, M.; Rupnik, M.S. Calcium Dependencies of Regulated Exocytosis in Different Endocrine Cells. Physiological Research 2011, 60, S29-S38.

38. Holz, G.G. Epac: A new cAMP-binding protein in support of glucagon-like peptide-1 receptor-mediated signal transduction in the pancreatic beta-cell. Diabetes 2004, 53, 5-13.

39. Ozaki, N.; Shibasaki, T.; Kashima, Y.; Miki, T.; Takahashi, K.; Ueno, H.; Sunaga, Y.; Yano, H.; Matsuura, Y.; Iwanaga, T., et al. cAMP-GEFII is a direct target of cAMP in regulated exocytosis. Nat Cell Biol 2000, 2, 805-811.

40. Seino, S.; Shibasaki, T. PKA-dependent and PKA-independent pathways for cAMP-regulated exocytosis. Physiol Rev 2005, 85, 1303-1342, doi:10.1152/physrev.00001.2005.

41. Kawasaki, H.; Springett, G.M.; Mochizuki, N.; Toki, S.; Nakaya, M.; Matsuda, M.; Housman, D.E.; Graybiel, A.M. A family of cAMP-binding proteins that directly activate Rap1. Science 1998, 282, 2275-2279, doi:10.1126/science.282.5397.2275.

42. Kelley, G.G.; Chepurny, O.G.; Schwede, F.; Genieser, H.G.; Leech, C.A.; Roe, M.W.; Li, X.; Dzhura, I.; Dzhura, E.; Afshari, $\mathrm{P}$. , et al. Glucose-dependent potentiation of mouse islet insulin secretion by Epac activator 8-pCPT-2'-O-Me-cAMP-AM. Islets 2009, 1, 260-265, doi:10.4161/isl.1.3.9645.

43. Leech, C.A.; Dzhura, I.; Chepurny, O.G.; Schwede, F.; Genieser, H.G.; Holz, G.G. Facilitation of ss-cell K(ATP) channel sulfonylurea sensitivity by a cAMP analog selective for the cAMP-regulated guanine nucleotide exchange factor Epac. Islets 2010, 2, 72-81.

44. Tsuboi, T.; Rutter, G.A. Insulin secretion by 'kiss-and-run' exocytosis in clonal pancreatic islet beta-cells. Biochem Soc Trans 2003, 31, 833-836.

45. Kang, G.; Chepurny, O.G.; Malester, B.; Rindler, M.J.; Rehmann, H.; Bos, J.L.; Schwede, F.; Coetzee, W.A.; Holz, G.G. cAMP sensor Epac as a determinant of ATP-sensitive potassium channel activity in human pancreatic beta cells and rat INS-1 cells. 2006; Vol. 573, pp 595-609.

46. Kang, G.; Leech, C.A.; Chepurny, O.G.; Coetzee, W.A.; Holz, G.G. Role of the cAMP sensor Epac as a determinant of KATP channel ATP sensitivity in human pancreatic Îc-cells and rat INS-1 cells. 2008; Vol. 586, pp 1307-1319.

47. Kang, G.; Chepurny, O.G.; Holz, G.G. cAMP-regulated guanine nucleotide exchange factor II (Epac2) mediates Ca2+-induced Ca2+ release in INS-1 pancreatic $\beta$-cells. The Journal of physiology 2001, 536, 375-385, doi:10.1111/j.1469-7793.2001.0375c.xd. 
48. Kang, G.; Joseph, J.W.; Chepurny, O.G.; Monaco, M.; Wheeler, M.B.; Bos, J.L.; Schwede, F.; Genieser, H.-G.; Holz, G.G. Epac-selective cAMP Analog 8-pCPT-2â€ Pancreatic İ_-Cells. Journal of Biological Chemistry 2003, 278, 8279-8285, doi:10.1074/jbc.M211682200.

49. Shibasaki, T.; Sunaga, Y.; Fujimoto, K.; Kashima, Y.; Seino, S. Interaction of ATP Sensor, cAMP Sensor, Ca2+ Sensor, and Voltage-dependent Ca2+ Channel in Insulin Granule Exocytosis. 2004; Vol. 279, pp 7956-7961.

50. Yasuda, T.; Shibasaki, T.; Minami, K.; Takahashi, H.; Mizoguchi, A.; Uriu, Y.; Numata, T.; Mori, Y.; Miyazaki, J.-i.; Miki, T., et al. Rim2\&\#x3b1; Determines Docking and Priming States in Insulin Granule Exocytosis. Cell Metabolism 2010, 12, 117-129, doi:10.1016/j.cmet.2010.05.017.

51. Hwang, M.; Go, Y.; Park, J.H.; Shin, S.K.; Song, S.E.; Oh, B.C.; Im, S.S.; Hwang, I.; Jeon, Y.H.; Lee, I.K., et al. Epac2a-null mice exhibit obesity-prone nature more susceptible to leptin resistance. International journal of obesity (2005) 2017, 41, 279-288, doi:10.1038/ijo.2016.208.

52. Song, W.J.; Mondal, P.; Li, Y.; Lee, S.E.; Hussain, M.A. Pancreatic beta-cell response to increased metabolic demand and to pharmacologic secretagogues requires EPAC2A. Diabetes 2013, 62, 2796-2807, doi:10.2337/db12-1394.

53. Benninger, R.K.; Zhang, M.; Head, W.S.; Satin, L.S.; Piston, D.W. Gap junction coupling and calcium waves in the pancreatic islet. Biophysical journal 2008, 95, 5048-5061, doi:10.1529/biophysj.108.140863.

54. Stožer, A.; Dolenšek, J.; Rupnik, M.S. Glucose-Stimulated Calcium Dynamics in Islets of Langerhans in Acute Mouse Pancreas Tissue Slices. PLoS ONE 2013, 8, e54638, doi:10.1371/journal.pone.0054638.

55. Bosco, D.; Haefliger, J.-A.; Meda, P. Connexins: Key Mediators of Endocrine Function. Physiological Reviews 2011, 91, 1393-1445, doi:10.1152/physrev.00027.2010.

56. S Šterk, M.; Dolenšek, J.; Bombek, L.K.; Markovič, R.; Zakelšek, D.; Perc, M.; Pohorec, V.; Stožer, A.; Gosak, M. Assessing the origin and velocity of $\mathrm{Ca} 2+$ waves in three-dimensional tissue: Insights from a mathematical model and confocal imaging in mouse pancreas tissue slices. Communications in Nonlinear Science and Numerical Simulation 2021, 93, 105495, doi:https://doi.org/10.1016/j.cnsns.2020.105495.

57. Dolenšek, J.; Stožer, A.; Skelin Klemen, M.; Miller, E.W.; Slak Rupnik, M. The Relationship between Membrane Potential and Calcium Dynamics in Glucose-Stimulated Beta Cell Syncytium in Acute Mouse Pancreas Tissue Slices. PLoS ONE 2013, 8, e82374, doi:10.1371/journal.pone.0082374.

58. Stozer, A.; Hojs, R.; Dolensek, J. Beta Cell Functional Adaptation and Dysfunction in Insulin Resistance and the Role of Chronic Kidney Disease. Nephron 2019, 143, 33-37, doi:10.1159/000495665.

59. Bavamian, S.; Klee, P.; Britan, A.; Populaire, C.; Caille, D.; Cancela, J.; Charollais, A.; Meda, P. Islet-cell-to-cell communication as basis for normal insulin secretion. Diabetes, Obesity and Metabolism 2007, 9, 118-132, doi:10.1111/j.1463-1326.2007.00780.x.

60. Benninger, R.K.; Piston, D.W. Cellular communication and heterogeneity in pancreatic islet insulin secretion dynamics. Trends in endocrinology and metabolism: TEM 2014, 10.1016/j.tem.2014.02.005, doi:10.1016/j.tem.2014.02.005.

61. Farnsworth, N.L.; Walter, R.; Piscopio, R.A.; Schleicher, W.E.; Benninger, R.K.P. Exendin-4 overcomes cytokine-induced decreases in gap junction coupling via protein kinase A and Epac2 in mouse and human islets. The Journal of physiology 2019, 597, 431-447, doi:10.1113/JP276106.

62. Benninger, R.K.; Hutchens, T.; Head, W.S.; McCaughey, M.J.; Zhang, M.; Le Marchand, S.J.; Satin, L.S.; Piston, D.W. Intrinsic islet heterogeneity and gap junction coupling determine spatiotemporal $\mathrm{Ca}(2)(+)$ wave dynamics. Biophysical journal 2014, 107, 2723-2733, doi:10.1016/j.bpj.2014.10.048.

63. Gosak, M.; Stozer, A.; Markovic, R.; Dolensek, J.; Perc, M.; Rupnik, M.S.; Marhl, M. Critical and Supercritical Spatiotemporal Calcium Dynamics in Beta Cells. Front Physiol 2017, 8, 1106, doi:10.3389/fphys.2017.01106.

64. Westacott, M.J.; Ludin, N.W.F.; Benninger, R.K.P. Spatially Organized beta-Cell Subpopulations Control Electrical Dynamics across Islets of Langerhans. Biophysical journal 2017, 113, 1093-1108, doi:10.1016/j.bpj.2017.07.021. 
65. Stozer, A.; Markovic, R.; Dolensek, J.; Perc, M.; Marhl, M.; Slak Rupnik, M.; Gosak, M. Heterogeneity and Delayed Activation as Hallmarks of Self-Organization and Criticality in Excitable Tissue. Front Physiol 2019, 10, 869, doi:10.3389/fphys.2019.00869.

66. Kravets, V.; Dwulet, J.M.; Schleicher, W.E.; Hodson, D.J.; Davis, A.M.; Piscopio, R.A.; Sticco-Ivins, M.; Benninger, R.K.P. Functional architecture of the pancreatic islets: First responder cells drive the first-phase [Ca\&lt;sup\&gt;2+\&lt;/sup\&gt;] response. bioRxiv 2020, 10.1101/2020.12.22.424082, 2020.2012.2022.424082, doi:10.1101/2020.12.22.424082.

67. Stožer, A.; Gosak, M.; Dolenšek, J.; Perc, M.; Marhl, M.; Rupnik, M.S.; Korošak, D. Functional Connectivity in Islets of Langerhans from Mouse Pancreas Tissue Slices. PLoS Comput Biol 2013, 9, e1002923, doi:10.1371/journal.pcbi.1002923.

68. Salem, V.; Silva, L.D.; Suba, K.; Georgiadou, E.; Neda Mousavy Gharavy, S.; Akhtar, N.; Martin-Alonso, A.; Gaboriau, D.C.A.; Rothery, S.M.; Stylianides, T., et al. Leader beta-cells coordinate $\mathrm{Ca}(2+)$ dynamics across pancreatic islets in vivo. Nat Metab 2019, 1, 615-629, doi:10.1038/s42255-019-0075-2.

69. Zmazek, J.; Klemen, M.S.; Markovič, R.; Dolenšek, J.; Marhl, M.; Stožer, A.; Gosak, M. Assessing Different Temporal Scales of Calcium Dynamics in Networks of Beta Cell Populations. Frontiers in physiology 2021, 12, 612233-612233, doi:10.3389/fphys.2021.612233.

70. Markovic, R.; Stozer, A.; Gosak, M.; Dolensek, J.; Marhl, M.; Rupnik, M.S. Progressive glucose stimulation of islet beta cells reveals a transition from segregated to integrated modular functional connectivity patterns. Scientific reports 2015, 5, 7845, doi:10.1038/srep07845.

71. Gosak, M.; Markovic, R.; Dolensek, J.; Slak Rupnik, M.; Marhl, M.; Stozer, A.; Perc, M. Network science of biological systems at different scales: A review. Phys Life Rev 2018, 24, 118-135, doi:10.1016/j.plrev.2017.11.003.

72. Gosak, M.; Stozer, A.; Markovic, R.; Dolensek, J.; Marhl, M.; Rupnik, M.S.; Perc, M. The relationship between node degree and dissipation rate in networks of diffusively coupled oscillators and its significance for pancreatic beta cells. Chaos (Woodbury, N.Y.) 2015, 25, 073115, doi:10.1063/1.4926673.

73. Johnston, N.R.; Mitchell, R.K.; Haythorne, E.; Pessoa, M.P.; Semplici, F.; Ferrer, J.; Piemonti, L.; Marchetti, P.; Bugliani, M.; Bosco, D., et al. Beta Cell Hubs Dictate Pancreatic Islet Responses to Glucose. Cell metabolism 2016, 24, 389-401, doi:10.1016/j.cmet.2016.06.020.

74. Rutter, G.A.; Hodson, D.J.; Chabosseau, P.; Haythorne, E.; Pullen, T.J.; Leclerc, I. Local and regional control of calcium dynamics in the pancreatic islet. Diabetes, obesity \& metabolism 2017, 19 Suppl 1, 30-41, doi:10.1111/dom.12990.

75. Mears, D.; Sheppard, N.F.; Atwater, I.; Rojas, E. Magnitude and Modulation of Pancreatic Beta-Cell Gap Junction Electrical Conductance In-Situ. Journal of Membrane Biology 1995, 146, 163-176.

76. Allagnat, F.; Martin, D.; Condorelli, D.F.; Waeber, G.; Haefliger, J.-A. Glucose represses connexin36 in insulin-secreting cells. Journal of Cell Science 2005, 118, 5335-5344, doi:10.1242/jcs.02600.

77. Hodson, D.J.; Mitchell, R.K.; Bellomo, E.A.; Sun, G.; Vinet, L.; Meda, P.; Li, D.; Li, W.H.; Bugliani, M.; Marchetti, P., et al. Lipotoxicity disrupts incretin-regulated human beta cell connectivity. J Clin Invest 2013, 123, 4182-4194, doi:10.1172/jci68459.

78. Haefliger, J.-A.; Martin, D.; Favre, D.; Petremand, Y.; Mazzolai, L.; Abderrahmani, A.; Meda, P.; Waeber, G.; Allagnat, F. Reduction of Connexin36 Content by ICER-1 Contributes to Insulin-Secreting Cells Apoptosis Induced by Oxidized LDL Particles. PLoS ONE 2013, 8, e55198, doi:10.1371/journal.pone.0055198.

79. Farnsworth, N.L.; Hemmati, A.; Pozzoli, M.; Benninger, R.K. Fluorescence recovery after photobleaching reveals regulation and distribution of connexin36 gap junction coupling within mouse islets of Langerhans. The Journal of physiology 2014, 592, 4431-4446, doi:10.1113/jphysiol.2014.276733.

80. Farnsworth, N.L.; Benninger, R.K. New insights into the role of connexins in pancreatic islet function and diabetes. FEBS Lett 2014, 588, 1278-1287, doi:10.1016/j.febslet.2014.02.035. 
81. Kothmann, W.W.; Massey, S.C.; O'Brien, J. Dopamine-stimulated dephosphorylation of connexin 36 mediates AII amacrine cell uncoupling. The Journal of neuroscience : the official journal of the Society for Neuroscience 2009, 29, 14903-14911, doi:10.1523/JNEUROSCI.3436-09.2009.

82. Lee, T.-M.; Lin, S.-Z.; Chang, N.-C. Both PKA and Epac pathways mediate N-acetylcysteine-induced Connexin43 preservation in rats with myocardial infarction. PloS one 2013, 8, e71878-e71878, doi:10.1371/journal.pone.0071878.

83. Somekawa, S.; Fukuhara, S.; Nakaoka, Y.; Fujita, H.; Saito, Y.; Mochizuki, N. Enhanced functional gap junction neoformation by protein kinase A-dependent and Epac-dependent signals downstream of cAMP in cardiac myocytes. Circ Res 2005, 97, 655-662, doi:10.1161/01.RES.0000183880.49270.f9.

84. Speier, S.; Rupnik, M. A novel approach to in situ characterization of pancreatic B-cells. Pflügers Archiv European Journal of Physiology 2003, 446, 553-558, doi:10.1007/s00424-003-1097-9.

85. Stožer, A.; Klemen, M.S.; Gosak, M.; Bombek, L.K.; Pohorec, V.; Rupnik, M.S.; Dolenšek, J. Glucose-dependent activation, activity, and deactivation of beta cell networks in acute mouse pancreas tissue slices. bioRxiv 2021, 10.1101/2020.03.11.986893, 2020.2003.2011.986893, doi:10.1101/2020.03.11.986893.

86. MacDonald, P.E.; Salapatek, A.M.; Wheeler, M.B. Glucagon-like peptide-1 receptor activation antagonizes voltage-dependent repolarizing $\mathrm{K}(+)$ currents in beta-cells: a possible glucose-dependent insulinotropic mechanism. Diabetes 2002, 51 Suppl 3, S443-447.

87. Hodson, D.J.; Tarasov, A.I.; Gimeno Brias, S.; Mitchell, R.K.; Johnston, N.R.; Haghollahi, S.; Cane, M.C.; Bugliani, M.; Marchetti, P.; Bosco, D., et al. Incretin-modulated beta cell energetics in intact islets of Langerhans. Mol Endocrinol 2014, 10.1210/me.2014-1038, me20141038, doi:10.1210/me.2014-1038.

88. Stožer, A.; Markovič, R.; Dolenšek, J.; Perc, M.; Marhl, M.; Slak Rupnik, M.; Gosak, M. Heterogeneity and Delayed Activation as Hallmarks of Self-Organization and Criticality in Excitable Tissue. Frontiers in Physiology 2019, 10, doi:10.3389/fphys.2019.00869.

89. Irles, E.; Neco, P.; Lluesma, M.; Villar-Pazos, S.; Santos-Silva, J.C.; Vettorazzi, J.F.; Alonso-Magdalena, P.; Carneiro, E.M.; Boschero, A.C.; Nadal, A., et al. Enhanced glucose-induced intracellular signaling promotes insulin hypersecretion: pancreatic beta-cell functional adaptations in a model of genetic obesity and prediabetes. Mol Cell Endocrinol 2015, 404, 46-55, doi:10.1016/j.mce.2015.01.033.

90. Kang, G.; Chepurny, O.G.; Malester, B.; Rindler, M.J.; Rehmann, H.; Bos, J.L.; Schwede, F.; Coetzee, W.A.; Holz, G.G. cAMP sensor Epac as a determinant of ATP-sensitive potassium channel activity in human pancreatic beta cells and rat INS-1 cells. The Journal of physiology 2006, 573, 595-609, doi:10.1113/jphysiol.2006.107391.

91. Britsch, S.; Krippeit-Drews, P.; Lang, F.; Gregor, M.; Drews, G. Glucagon-like peptide-1 modulates Ca2+ current but not K+ATP current in intact mouse pancreatic B-cells. Biochem Biophys Res Commun 1995, 207, 33-39, doi:10.1006/bbrc.1995.1149.

92. Do, O.H.; Low, J.T.; Gaisano, H.Y.; Thorn, P. The secretory deficit in islets from db/db mice is mainly due to a loss of responding beta cells. Diabetologia 2014, 57, 1400-1409, doi:10.1007/s00125-014-3226-8.

93. Gilon, P.; Henquin, J.C. Influence of membrane potential changes on cytoplasmic Ca2+ concentration in an electrically excitable cell, the insulin-secreting pancreatic B-cell. Journal of Biological Chemistry 1992, 267, 20713-20720.

94. MacDonald, P.E.; Rorsman, P. Oscillations, Intercellular Coupling, and Insulin Secretion in Pancreatic $\beta$ Cells. PLoS Biol 2006, 4, e49, doi:10.1371/journal.pbio.0040049.

95. Jonkers, F.C.; Henquin, J.-C. Measurements of Cytoplasmic Ca2+ in Islet Cell Clusters Show That Glucose Rapidly Recruits $\beta$-Cells and Gradually Increases the Individual Cell Response. Diabetes 2001, 50, 540-550, doi:10.2337/diabetes.50.3.540.

96. Gonzalez, A.; Merino, B.; Marroqui, L.; Neco, P.; Alonso-Magdalena, P.; Caballero-Garrido, E.; Vieira, E.; Soriano, S.; Gomis, R.; Nadal, A., et al. Insulin hypersecretion in islets from diet-induced hyperinsulinemic obese female mice is 
associated with several functional adaptations in individual beta-cells. Endocrinology 2013, 154, 3515-3524, doi:10.1210/en.2013-1424.

97. Bertuzzi, F.; Davalli, A.M.; Nano, R.; Socci, C.; Codazzi, F.; Fesce, R.; Di Carlo, V.; Pozza, G.; Grohovaz, F. Mechanisms of coordination of $\mathrm{Ca}^{2+}$ signals in pancreatic islet cells. Diabetes 1999, 48, 1971-1978, doi:10.2337/diabetes.48.10.1971.

98. Speier, S.; Gjinovci, A.; Charollais, A.; Meda, P.; Rupnik, M. Cx36-Mediated Coupling Reduces $\beta$-Cell Heterogeneity, Confines the Stimulating Glucose Concentration Range, and Affects Insulin Release Kinetics. Diabetes 2007, 56, 1078-1086, doi:10.2337/db06-0232.

99. Satin, L.S.; Zhang, Q.; Rorsman, P. "Take Me To Your Leader": An Electrophysiological Appraisal of the Role of Hub Cells in Pancreatic Islets. Diabetes 2020, 69, 830-836, doi:10.2337/dbi19-0012.

100. Santos, R.M.; Rosario, L.M.; Nadal, A.; Garcia-Sancho, J.; Soria, B.; Valdeolmillos, M. Widespread synchronous Ca oscillations due to bursting electrical activity in single pancreatic islets. Pflügers Archiv European Journal of Physiology 1991, 418, 417-422, doi:10.1007/bf00550880.

101. Bergsten, P. Role of Oscillations in Membrane Potential, Cytoplasmic Ca2+, and Metabolism for Plasma Insulin Oscillations. Diabetes 2002, 51, S171-S176, doi:10.2337/diabetes.51.2007.S171.

102. Gromada, J.; Ding, W.-G.; Barg, S.; Renström, E.; Rorsman, P. Multisite regulation of insulin secretion by cAMP-increasing agonists: evidence that glucagon-like peptide 1 and glucagon act via distinct receptors. Pflügers Archiv European Journal of Physiology 1997, 434, 515-524.

103. Miki, T.; Minami, K.; Shinozaki, H.; Matsumura, K.; Saraya, A.; Ikeda, H.; Yamada, Y.; Holst, J.J.; Seino, S. Distinct effects of glucose-dependent insulinotropic polypeptide and glucagon-like peptide-1 on insulin secretion and gut motility. Diabetes 2005, 54, 1056-1063, doi:10.2337/diabetes.54.4.1056.

104. Meda, P. The in vivo beta-to-beta-cell chat room: connexin connections matter. Diabetes 2012, 61, 1656-1658, doi:10.2337/db12-0336.

105. Ravier, M.A.; Güldenagel, M.; Charollais, A.; Gjinovci, A.; Caille, D.; Söhl, G.; Wollheim, C.B.; Willecke, K.; Henquin, J.-C.; Meda, P. Loss of Connexin36 Channels Alters $\beta$-Cell Coupling, Islet Synchronization of Glucose-Induced Ca2+ and Insulin Oscillations, and Basal Insulin Release. Diabetes 2005, 54, 1798-1807, doi:10.2337/diabetes.54.6.1798.

106. Segretain, D.; Falk, M.M. Regulation of connexin biosynthesis, assembly, gap junction formation, and removal. Biochimica et biophysica acta 2004, 1662, 3-21, doi:10.1016/j.bbamem.2004.01.007.

107. Laird, D.W. Life cycle of connexins in health and disease. Biochem J 2006, 394, 527-543, doi:10.1042/bj20051922.

108. Urschel, S.; Hoher, T.; Schubert, T.; Alev, C.; Sohl, G.; Worsdorfer, P.; Asahara, T.; Dermietzel, R.; Weiler, R.; Willecke, K. Protein kinase A-mediated phosphorylation of connexin36 in mouse retina results in decreased gap junctional communication between AII amacrine cells. The Journal of biological chemistry 2006, 281, 33163-33171, doi:10.1074/jbc.M606396200.

109. Ivanova, E.; Yee, C.W.; Sagdullaev, B.T. Increased phosphorylation of Cx36 gap junctions in the AII amacrine cells of RD retina. Front Cell Neurosci 2015, 9, 390, doi:10.3389/fncel.2015.00390.

110. Pidoux, G.; Tasken, K. Anchored PKA as a gatekeeper for gap junctions. Commun Integr Biol 2015, 8, e1057361, doi:10.1080/19420889.2015.1057361.

111. Li, X.; Lynn, B.D.; Nagy, J.I. The effector and scaffolding proteins AF6 and MUPP1 interact with connexin36 and localize at gap junctions that form electrical synapses in rodent brain. European Journal of Neuroscience 2012, 35, 166-181, doi:https://doi.org/10.1111/j.1460-9568.2011.07947.x.

112. Rupnik, M. All together now: exocytose or fail. Islets 2009, 1, 78-80, doi:10.4161/isl.1.1.8757. 